\title{
SURPRISING EPISODIC RECRUITMENTAND GROWTH OF ANTARCTIC SPONGES: IMPLICATIONS FOR ECOLOGICAL RESILIENCE
}

Paul Dayton, ${ }^{\mathrm{a},}$, Shannon Jarrell ${ }^{\mathrm{a}}$, Stacy Kim ${ }^{\mathrm{b}}$, Simon Thrush ${ }^{\mathrm{c}}$, Kamille Hammerstrom, ${ }^{\mathrm{b}}$ Marc Slattery ${ }^{\mathrm{d}, 1}$, Edward Parnell ${ }^{\mathrm{a}}$

${ }^{a}$ Scripps Institution of Oceanography, La Jolla, CA 92075

${ }^{\mathrm{b}}$ Moss Landing Marine Laboratories, Moss Landing, CA 95039

${ }^{\mathrm{c}}$ Institute of Marine Science, University of Auckland, Private Bag 92019, Auckland 1142, New Zealand

${ }^{\mathrm{d}}$ University of Alabama at Birmingham, Department of Biological Sciences, Birmingham, AL 35294 (address when work completed)

* Corresponding author, pdayton@ucsd.edu

${ }^{1}$ University of Mississippi, Department of BioMolecular Sciences, Divisions of Environmental Toxicology and Pharmacognosy, P.O. Box 1848, University, MS 38677 (present address) 


\begin{abstract}
Sponges are the most conspicuous component of the Antarctic benthic ecosystem, a system under stress both from climate change and fishing activities. Observations over four decades are compiled and reveal extremely episodic sponge recruitmentand growth.Recruitment occurred under different oceanographic conditions on both sides of McMurdo Sound. Most of the sponges appear to have recruited in the late 1990s-2000. Observations from 2000 to 2010 follow thirty years of relative stasis with very little sponge recruitment or growth followed by a general pattern of recruitment by some forty species of sponges. That there was almost no recruitment observed on natural substrata emphasizes the contrast between potential and realized recruitment. This unique data set was derived from a region noted for physical stasis, but theepisodic ecological phenomena highlightthe importance of rare events. Against a background of intermittent food resources and the low metabolic costs of stasis, understanding the causes of irregular larval supply, dispersal processes, recruitment success and survivorship becomes critical to predicting ecosystem dynamics and resilience in response to increasing environmental change. Our time-series emphasizes that long-term data collection is essential for meaningful forecasts about environmental change in the unique benthic ecosystems of the Antarctic shelf.
\end{abstract}

5 Keywords: Antarctica, sponges, recruitment, time-series, resilience

\title{
1.1 Introduction
}

All ecosystems are impacted by human activity, including climate change. To understand the consequences of environmental change one needs to understand the mechanisms underlying the ecological resilience to both natural and anthropogenic disturbances. This understanding allows predictive capacities on ecosystem response to perturbations. Resilience is supported by resistance to the disturbance, and rate of succession leading to recovery from the perturbations. The successional capacity of populations and communities to respond and recover from change is related to the time-scales of recruitment, dispersal and growth. 
Here we consider long-term data on the benthic ecosystem of McMurdo Sound, Antarctic.The Antarctic benthos areoften considered stable due to the apparent persistence of communities over multiple years in the presence of a relatively constant oceanographic environment. Nevertheless, long-term observations have revealed profound changes in benthic community structure associated with episodic recruitment (Dayton, 1989; Dayton et al., 2013). This paper addresses the recruitment component of resilience with long-term observations of recruitment and growth of some 40 sponge species on artificial, experimental structures located in very different environmental settings on each side of McMurdo Sound, as well as the results of a settlement experiment on natural substrata. The paper extends long-term ecological observations of habitatforming foundation species to over 40 years. This unique data set, interpreted with extensive natural history information, provides a novel perspective on the recruitment and growth of sponges and other selected invertebrates of McMurdo Sound, Antarctica.

Polar climate change is associated with the break-up of ice shelves, and increased scour from the resulting icebergs, as well as changes in sedimentation and productivity associated with changes in sea ice cover. Oceanographically isolated for approximately35 M years, Antarctic shelf benthos evolved in the veritable absence of shell-crushing predators(e.g. crabs, rays) and under extremely stenothermic conditions (Gili et al., 2006), and is now responding to rapid changes in ice cover (Turner, et al., 2014, Gutt et al., 2015a). As oceanographic barriers become leaky with climate change,species invasions from the north or simple expansion of ranges represent another episodic event with broad-scale consequences (Aronson et al., 2015). There are also impacts of various fisheries, especially long-line fishing gear being lost and dragged over the bottom, flattening and dislocating invertebrates and depleting ecologically important fish.

Antarctic benthic communities are reasonably well described (Gutt, 2007), and there is a preliminary understanding of disturbances in Antarctic benthic communities (Thrush et al., 2006). However, there has been little opportunity to study successional patterns following disturbance to the seafloor in the Antarctic because we lack the temporal baseline critical to understanding successional changes. The studies that have been conducted track individual disturbance events and include recruitment in iceberg scours (Arntz et al., 1994,Gutt, 2001,Gutt and Piepenburg, 2003), observations of successional patterns after a large section of the Larsen Ice Shelf broke up 
(Gutt et al., 2011,2013,Fillinger et. al, 2013), the recession of the glacier in Potter's Cove (Torre et al., 2012,Sahade et al., 2015) and increased ice scour (Barnes et al., 2014). These extremely valuable studies address single events but provide limited insight into the consequences of longer time scale variation in dispersal, recruitment, growth, and survivorship in the Antarctic benthos. The long-term observations of foundation sponge species presented here allow interpretation of variability and succession in the relatively stable environment of McMurdo Sound, Antarctica.

\subsection{Background}

\subsubsection{General Background}

McMurdo Sound (Fig. 1) is characterized by strong East-West and North-South gradients reflecting the sources and advection of primary production (Dayton and Oliver, 1977, Barry, 1988, Thrush et al., 2006). The east sound is characterized by southerly currents that bring phytoplankton from a large and productive polyna north of Ross Island (Barry et al., 2003). In contrast, the mainland or west side of McMurdo Sound is characterized by slow, northerly currents sourced beneath the Ross Ice Shelf that bathe the Explorers Cove regions of New Harbour (Fig. 1) with very poor planktonic food resources (Barry, 1988, Barry and Dayton, 1988). Thrush et al. (2006) offers a comprehensive review of patterns in productivity and disturbance. The natural sea bottom varies greatly on either side of McMurdo Sound (Fig. 1). Most of the Ross Island substrata are volcanic gravels with occasional lava extrusions forming rocky ridges. In contrast, the southwest side of the sound from Explorers Cove in New Harbour to the south is sand with gravel along the shore (Dayton and Oliver, 1977).

\section{Figure 1, map goes near here.}

The benthic community of the eastern side of McMurdo Sound has a long history of ecological research starting with collections from the historic age of Scott and Shackleton to the IGY (International Geophysical Year 1957-58) era of the late 1950s and early 1960s (Dearborn, 1965,Bullivant and Dearborn, 1967). Biota of the southern Hut Point Peninsula is conspicuously zoned by anchor ice (Dayton et al., 1970) that keeps the shallow zone bare to 10-15 m; the next 
zone $(15-30 \mathrm{~m})$ is periodically disturbed by ice and is characterized by ephemeral cnidarians, Bryozoa, and some ephemeral sponges on a gravel bottom. Anchor ice is rare below $30 \mathrm{~m}$ along the southern Hut Point Peninsula, and the zone from 30-50 m is characterized by sponges on a matrix of sponge spicules. In depths below 45-50 $\mathrm{m}$ the predominant fauna shifts from sponges to Bryozoa along the southern part of Hut Point Peninsula. The fauna north of Arrival Heights change as the substrata is characterized by loose gravel and increased light that allows much more microalgal growth (Dayton et al., 1986).

\subsubsection{Sponge Recruitment.}

The recruitment and growth of the sponges in McMurdo Sound were initially investigated in cagesand the adjacent controls starting in 1967. Twenty species of sponges showed no measurable growth; only Mycale acerata, Haliclonascotti and Haliclonadancoi exhibited limited recruitment and relatively fast growth, with $M$. acerata showing a strong competitive dominance even though it was rare (Dayton et al., 1974). These sponges were revisited in 1974-77, and several species had measurable but very slow growth; with the exceptions of $M$. acerata and some Haliclonaspecies, the vast majority of sponges grew very slowly between 1967 and 1977. However, Dayton (1979) reported surprisingly fast growth and budding of Rossellapodagrosa. In general, slow sponge growth rates were observed through 1989 with almost no recruitment. A few photographs of cages in 1998 showed no settlement or growth beyond a few specimens of $H$. scotti, M. acerata, and the calcareous sponge, Leucascusleptoraphis. These observations of very limited sponge recruitment over 30 years within caging experiments and adjacent controlscontributed to the paradigm of slow settlement and growth of Antarctic sponges.

Over the last 40 years there have been episodic anchor ice disturbances and recruitment events in McMurdo Sound in which the patterns differed between the two sides of the sound. In the 1970s there was virtually no anchor ice disturbance, and this coincided with heavy east sound recruitment of the demospongeHomaxinellabalfourensis over the middle depth zone (15-30 m), but never in the deeper sponge community where the predominate substratum is a thick mat of sponge spicules. Anchor ice returned in the 1980s, removing H. balfourensis, and by 1989 the area was virtually clear of sponges (Dayton, 1989). In contrast, experimental arrays and moored 
settling plates established in 1974 on the west side of McMurdo Sound had virtually no recruitment during the 1970s when the east sound experienced the massive H. balfourensis recruitment (Dayton, 1989). While the east sound was exposed to heavy anchor ice in the 1980s, the structures and settling plates moored in the water column on the west side of the sound were colonized by Hydrozoa, some Bryozoa, a few $H$. scotti and large numbers of $H$. balfourensis.

Repeat visits to each site were opportunistic and infrequent, but it was clear the two sides of McMurdo Sound had different, but very limited patterns of recruitment during the 1960s through at least the mid 1990s.

Unique long-term observations of recruitment and growth on artificial, experimental structures located on each side of McMurdo Sound are presented, as well as the results of a settlement experiment on natural rocky substrata. Furthermore, this paper updates previous observations of the remarkable recruitment and growth of the giant hexactinellid sponge, Anoxycalyxjoubini, to include photographs from 2004 (Dayton et al., 2013).

\subsection{Materials and Methods}

\subsubsection{Artificial and Natural Structures}

Various artificial and natural structures were deployed and remained in situ for 30-40 years. Although they differ in details (see Table 1 and Supplement A), the common element of the artificial substrata is that they provided settlement surfaces both in contact with the substratum, inviting natural predators to move onto the settlement surfaces, and surfaces elevated above the seafloor community, limiting the effects of competition and predation on recruitment and juvenile mortality. Words in bold indicate structures referred to throughout the text. Structures in the east sound sites included arrays of settling plates at depths of about 23, 30 and $40 \mathrm{~m}$. The plates, composed of asbestos board or scoured Plexiglas, were attached to wood or rebar stakes 0.5 and $1.0 \mathrm{~m}$ off the ground. These structures were orientated horizontally or at $45^{\circ}$ angle to the seafloor. Plates were also placed on the seafloor beside sponges and on cages and racks. They were placed Cape Armitage, Hut Point, Cinder Cones, Turtle Rock and Cape Evans. 


\section{Table 1, goes near here.}

Natural substrate experiments were initiated in October 1992 when natural volcanic rocks $(\sim 10$ $\mathrm{cm}^{2}$ ) were autoclaved and pieced together into replicate settlement plots of $0.25 \mathrm{~m}^{2}$ at sites at Arrival Heights and Cape Evans. These plots were situated at depths of 5, 20, and $35 \mathrm{~m}$.In each site a total of six plots approximately $5 \mathrm{~m}$ apart were established, three of which were enclosed by a $\operatorname{Vexar}{ }^{\circledR}$ cage $(25 \times 25 \times 15 \mathrm{~cm}$ tall; $1 \mathrm{~cm}$ mesh size $)$. Settlement plots were observed until December 1992, and again from August 1993 until December 1994 when the experiment was terminated. At that time, the substrata were recovered and analyzed. Differences in recruitment were visualized using non-Metric Dimensional Scaling (nMDS) plots (Supplement A) and quantified using PERMANOVA+ (Anderson et al., 2008).

Twenty of the cagesoriginally established in 1967 were followed through 2010 at depths ranging from 30-55 m at Cape Armitage and north Hut Point. Soft sediment experiments were conducted in 1975-78 in which sediment was placed in washbasins and freezer containers and held above the bottom with various racks.In 1974 floats suspending various settlement surfaces were established to evaluate larval availability in the water column.It was thought at the time that most of the invertebrate larvae had benthic life styles and did not disperse in the water column and these floats were designed to test that generalization. These floaters were suspended 4-20 m above the sea floor on the east and west sides of the sound. Four large cages made from pipes (referred to as pipe cages) were established in 1967 at both Hut Point and Cape Armitage.See Supplement A for additional details.

Finally, three incidental (not placed as part of experiments) artificial structures were included in our analysis: a large wooden ship's gangplank dropped in 1960-61 at Hut Point at a depth of 25 $30 \mathrm{~m}$; a "Weasel" (small tracked vehicle) that sunk in about $25 \mathrm{~m}$ depth off Hut Point in 1961; and an insulated metal casing that fell through the ice at Cape Armitage in 1961 at a depth of 23 m. 
All data collection through 1998 utilized scuba, and because of time and depth limitations most was performed photographically. Limited scuba and ROV surveys were conducted between 2002 and 2007. In 2010 we revisited all of the sites with either divers or ROV. At this time two floaters were recovered and several more were placed at the sites with fresh settling surfaces. Sponges were measured using parallel lasers on cameras, $20 \mathrm{~cm}$ apart on the scuba camera and $10 \mathrm{~cm}$ apart on the ROV. Sizes and percent cover of sponges were analyzed from the photographs with Image J. The biomass (wet weight in grams) of the sponges was estimated from regressions published in Dayton et al. (1974). Those species not measured at that time are presented here with the 1974 regressions applied to the 1974 sponges they most closely resemble.

McMurdo Sound had some of the most extreme underwater visibility in the world. It was so remarkable that it wasmeasured at $290 \mathrm{~m}$ in October 1967, by looking up towards the shore or to markers on the ice. In the 1970s and 1980s when possible we obtained estimates of visibility based on the same view as the 1967 measurement.Divers experienced in the area noticed marked declines in the visibility during the 2000s (Rob Robbins, pers. comm.).Visibility was also measured directly in 1994, and by 2014 was less than $60 \mathrm{~m}$.

\subsection{Time Line}

Table 1 reviews the changes in the important environmental parameters and outlines the timeline of the various structures emplaced on the east and west sides of the sound. The amount of anchor ice formation is an important disturbance of the more shallow habitats, and it varied over time. The amount of benthic microalgal productivity is limited by light, which is influenced by the ice thickness. The underwater visibility varied depending on the amount of plankton in the water column. In 2000 large parts of the Ross Ice Shelf began to calve off, and they grounded along the north side of McMurdo Sound, blocking the currents that normally flow into the east sound with plankton from a large polyna.

\subsection{Sponge Taxonomy}


Identification of the sponges has proven challenging. Identifications are listed in Tables 2, 3, and 4 and represent our best suggestions, and Supplement B includes a brief summary of what we know of each sponge.In some cases we consistently differentiated different morphs of what turned out to be one species and following the example in Barthel and Gutt (1992) we simply differentiated them as I and II.

\subsection{Results}

\subsubsection{Geographic Site Differences}

The east and west sides of McMurdo Sound offer an extreme ecological contrast (Dayton and Oliver, 1977).The east side along Ross Island is relatively eutrophic with volcanic gravels and rocky ridges whereas the west side is oligotrophic and is characterized by soft, sandy substrata. Thus we present results for each side of the sound separately, focusing on the recruitment patterns on the different types of substrata. Limited and irregular observations confounded with changing environmental conditions and the loss of the structures over time restrict statistical analysis.

\subsection{East Sound}

\subsubsection{Plates}

In 1975 the top surfaces of the settling plates emplaced in 1974 had only a few very smallserpulid polychaetes and sometimes some small hydroids, while the bottom sides of the plates were virtually clean except for small serpulid polychaetes (See Supplement A). In the early austral winter of 1977 the plates were covered with a thick layer of Phaeocystis spp. from the late summer plankton bloom (J.S. Oliver, pers. comm.). Each austral spring the phytoplankton deposits are seen to have disappeared during the winter; presumably they fuel some of the benthic deposit feeders, although it is not known what species grazed the tops of the plates. ByNovember 1977 the top surfaces varied, but included scattered serpulids, Hydrozoa and Bryozoa. There were also scattered flatworms, and mollusc egg masses. The bottom surfaces, 
however, had considerable numbers of several species of serpulids and Bryozoa and some very small compound tunicates (See Supplement A). There were also several species of unidentified egg masses.

By the mid-1980s, some ten years after the settling plates were established, the plates supported above the substratum were colonized by Hydrozoa, especially Hydrodendron arboretum, the solitary tunicate Cnemidocarpaverrucosa, and the soft coral Alcyoniumantarcticum. Plates started falling over in the 1980sand were almost always kept clean on the bottom by Odontastervalidus and Sterechinusneumayeri, emphasizing the importance of predation. By 2003 there were five plates supported off the bottom with healthy colonies of A. antarcticum, $H$. scotti, H. dancoi, and M. acerata. Those plates with sea urchins showed clear observations of the urchin grazing (see photo in Supplement A). By 2004 three more species had settled on the top of these plates (L. leptoraphis, H.balfourensis, and H. arboretum) and two more species had settled on the bottom (H. scotti and Rossella levis). Most recently in 2010, three depths of roughly 23,30 , and $40 \mathrm{~m}$ depths were photographed. There were no standing arrays at $23 \mathrm{~m}$ but some of the fallen plates had lush growths of Bryozoa and A. antarcticum (see Supplement A).There was only one plate left supported above the bottom at $30 \mathrm{~m}$, and it had C. verrucosa and many $H$. balfourensis, $H$. scotti, Isodictyasp., "Pipe Sponge", Microxinasp.,Corymorphaparvula, Corymorphamicrorhiza, five unidentified colonial Hydrozoa, and a tube worm. In contrast, the bottom plate was being grazed by $S$. neumayeriand Odontastervalidus and it had a few A. antarcticum and Bryozoa. There were two plates standing at $40 \mathrm{~m}$, and the top plates had a thin cover of Hydrozoa and Bryozoa as well as scattered $A$. antarcticum and three recently settled Hydrodendron arboretum. There was also a single young Mycale acerata. Again the bottom plate was relatively clean with scattered Bryozoa with a large Phorbasareolatus or Kirkpatrickiacoulmani on the bottom adjacent to and overgrowing the plate (see Supplement A). Two of the top Cape Evans plates at $25 \mathrm{~m}$ supported two large A. joubiniin 2010. Although we had observed A. joubinisettling on our artificial substrata elsewhere (Dayton et al., 2013), this was unexpected because these were the only A. joubinito have grown on the small settling plates. 
Table 1.Timeline of environmental variables and structures.Anchor ice (1-5) ranking based on subjective estimated percent cover $(1=$ none, $2=0-10 \%, 3=10-20 \%, 4=20-40 \%, 5=60-75 \%)$,and in parentheses, maximum depth of occurrence $(1=$ none, $3=20 \mathrm{~m}, 4$ $=25 \mathrm{~m}, 5=33 \mathrm{~m}$ ). Ice thickness is in approximate meters, and visibility (m) (looking up from depth) was measured in 1967 and 1994and estimated in other years.Iceberg blocking is listed as + (present) or - (absent). The numbers for structures is the total number of sponge species recorded for each year. “_“= structure in place but not observed.

\begin{tabular}{|c|c|c|c|c|c|c|c|c|c|c|c|}
\hline & Year(s) & $1960-64$ & $1967-68$ & $1974-78$ & $1985-89$ & 1992-94 & 1998 & 2002 & 2004 & 2007 & 2010 \\
\hline \multirow{4}{*}{ 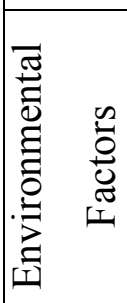 } & Anchor Ice & $5(5)$ & $5(5)$ & $1(1)$ & $4(5)$ & & & & 1 (2) & & $3(4)$ \\
\hline & Ice Thickness (m) & 6 & 4 & 2 & 3 & & & 4 & 4.5 & 8 & 8 \\
\hline & Visibility (m) & & 290 & 270 & 240 & 290 & & & & & $<60$ \\
\hline & Iceberg Block & - & - & - & - & - & - & + & + & + & + \\
\hline \multirow{7}{*}{ 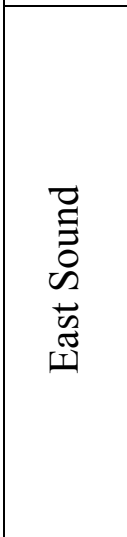 } & Plates & & & 0 & 4 & - & - & - & - & - & 6 \\
\hline & Rocks & & & & & 12 & & & & & \\
\hline & Cages & & 3 & 3 & 4 & - & 4 & - & - & - & 27 \\
\hline & Washbasin & & & 0 & 0 & - & - & - & 8 & - & 12 \\
\hline & Gangplank & & 0 & 1 & 0 & - & - & - & 12 & - & 12 \\
\hline & Casing & - & 0 & 0 & 0 & - & - & - & - & - & 2 \\
\hline & Floaters & - & 0 & 1 & 3 & - & 2 & - & - & - & 6 \\
\hline \multirow{3}{*}{ 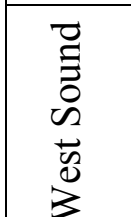 } & Washbasin & & & 0 & 0 & - & - & 2 & 2 & - & 2 \\
\hline & Racks & & & 0 & 1 & - & - & - & 5 & - & 17 \\
\hline & Floaters & & & 0 & 1 & - & - & 5 & 7 & - & 14 \\
\hline
\end{tabular}




\subsubsection{Natural Rocks}

Settlement on natural volcanic substrata enclosed in predator exclusion cages (1993 - 1994) differed from settlement on artificial or natural substrates in the earlier years. Nine sponge species, two cnidarians, and a red alga were found on the rocks but not artificial surfaces (Table 2). With few exceptions (i.e., the stoloniferan soft coral Clavulariafrankliniana, and the serpulids), the number of recruits of each species averaged $<1$ per settlement plot, with caging enhancing recruitment success (see analysis in Supplement A). There were strongdifferences in depth distributions of these species, and a cage $x$ depth interaction $(p<0.001)$ as evaluated with non-Metric Dimensional Scaling (nMDS) plots (Supplement A) and quantified using PERMANOVA+ (Anderson et al., 2008).

\section{Table 2 near here}

\subsubsection{Cages}

There was very little sponge recruitment within or on the cages between 1967 and 1998 at Cape Armitage, and 1967 and 2004 at Hut Point. At Hut Point by 2004 there was sparse recruitment of Bryozoa, Hydrozoa, soft corals, tunicates, and a few sponges, $H$. scotti, L. leptoraphis, $H$. balfourensis and Hemigelliusfimbriatus. One small $H$. fimbriatus showed no growth between 1967 and 1968, 10-15 cm over the next nine years (Dayton, 1979), and explosive growth between 1984 and 2010 (Supplement A). Dayton (1979) noted the great variability in growth of this species within and between individuals, and this is the only $H$. fimbriatus we have seen with such a massive growth surge.

Knowing that there was very little sponge recruitment on the cages or other structures between 1967 and 1998 at Cape Armitage and 2004 at Hut Point, we were surprised to find over 25 species of sponges growing on the cages and racks at Hut Point and Cape Armitage by 2002 2010 (Figure 2). Tables 3 and 4 compare the numbers, percent cover, and biomass of species for all of the Cape Armitage and Hut Point cages. The data are presented for the entire cage as well 
Table 2.Settlement patterns to natural substrata on Ross Island, Antarctica.Recruits to settlement plots $\left(0.25 \mathrm{~m}^{2}\right)$, caged ( $\left.\mathrm{n}=3\right)$ and uncaged ( $\mathrm{n}=3)$, at two sites (Arrival Heights and Cape Evans) and three depths within each site (5, 20, and $35 \mathrm{~m})$ were quantified after 15 months.Data in the table include the settlement depths, and the mean ( $\pm 1 \mathrm{SE})$ number of recruits to each caged settlement plot.There was virtually no recruitment to uncaged plots so these data are not reported.A dash (-) indicates the species was not found at that depth.

\begin{tabular}{|c|c|c|c|c|c|c|}
\hline & \multicolumn{3}{|c|}{ Arrival Heights } & \multicolumn{3}{|c|}{ Cape Evans } \\
\hline Species & $5 \mathrm{~m}$ & $20 \mathrm{~m}$ & $35 \mathrm{~m}$ & $5 \mathrm{~m}$ & $20 \mathrm{~m}$ & $35 \mathrm{~m}$ \\
\hline \multicolumn{7}{|l|}{ Poriferans } \\
\hline Calyx arcuarius & - & - & $0.17 \pm 0.17$ & - & $0.33 \pm 0.33$ & $0.17 \pm 0.17$ \\
\hline Cinachyraantarctica & - & $0.17 \pm 0.17$ & $1.33 \pm 0.49$ & - & - & $0.17 \pm 0.17$ \\
\hline Dendrillaantarctica & - & - & $0.67 \pm 0.33$ & - & - & - \\
\hline Homaxinellabalfourensis & $0.67 \pm 0.49$ & $4.33 \pm 1.03$ & $0.17 \pm 0.17$ & - & $3.33 \pm 0.62$ & - \\
\hline Inflatella belli & - & - & $0.17 \pm 0.17$ & - & - & $0.17 \pm 0.17$ \\
\hline Isodictyasetifera & - & $0.17 \pm 0.17$ & $0.17 \pm 0.17$ & - & - & - \\
\hline Kirkpatrickiavariolosa & - & - & $0.5 \pm 0.34$ & - & $0.33 \pm 0.21$ & $0.17 \pm 0.17$ \\
\hline Leucascusleptoraphis & - & $0.33 \pm 0.21$ & $0.17 \pm 0.17$ & - & $0.33 \pm 0.33$ & $0.67 \pm 0.33$ \\
\hline Mycale acerata & - & $0.33 \pm 0.21$ & $0.17 \pm 0.17$ & - & $0.17 \pm 0.17$ & - \\
\hline Polymastiainvaginata & - & $0.17 \pm 0.17$ & - & - & - & - \\
\hline Rossellapodagrosa & - & - & $0.83 \pm 0.31$ & - & - & - \\
\hline Tetillaleptoderma & - & $0.17 \pm 0.17$ & $0.33 \pm 0.21$ & - & - & $0.17 \pm 0.17$ \\
\hline \multicolumn{7}{|l|}{ Cnidarians } \\
\hline Alcyoniumpaessleri & - & - & $0.17 \pm 0.17$ & - & - & $0.17 \pm 0.17$ \\
\hline Clavulariafrankliniana & $11.0 \pm 5.56$ & $15.83 \pm 7.65$ & $9.67 \pm 4.30$ & $0.83 \pm 0.48$ & $7.83 \pm 3.57$ & $3.83 \pm 1.96$ \\
\hline Lampraparvula & $0.17 \pm 0.17$ & $0.50 \pm 0.34$ & $0.33 \pm 0.33$ & - & $0.33 \pm 0.33$ & $0.67 \pm 0.67$ \\
\hline \multicolumn{7}{|l|}{ Ascidians } \\
\hline Cnemidocarpaverrucosa & - & $0.17 \pm 0.17$ & - & - & $0.50 \pm 0.34$ & $0.50 \pm 0.34$ \\
\hline \multicolumn{7}{|l|}{ Algae } \\
\hline Phyllophoraantarctica & - & - & - & $0.33 \pm 0.33$ & $0.83 \pm 0.40$ & $0.17 \pm 0.17$ \\
\hline Unidentified serpulids & $5.83 \pm 3.04$ & $9.33 \pm 4.56$ & $0.50 \pm 0.34$ & $7.17 \pm 3.54$ & $10.17 \pm 4.66$ & $0.17 \pm 0.17$ \\
\hline Unidentified Bryozoa & - & - & $0.17 \pm 0.17$ & - & - & $0.50 \pm 0.34$ \\
\hline
\end{tabular}


as the tops alone, allowing an evaluation of the sides versus the tops, and we see that there are many more species on the sides. There are strong tidal currents (Barry, 1988) that can transport passive particles along the bottom, and we occasionally observed the small $(0.3-1.0 \mathrm{~cm}) R$. podagrosa buds floating off the bottom. The sides of the cages were no more than $30 \mathrm{~cm}$ high and probably within the boundary-layer of reduced currents, thus it might be that the propagules of the species that tend only to be on the sides simply drift in the currents where they are collected by the cages as seen in Figure 2.

\section{Figure 2 near here}

Only a few species contributed the bulk of the biomass on the cages. The biomass on Cape Armitage cages (Table 3) was dominated by M. acerata.,T. leptoderma, $H$. scotti, and $H$. fimbriatus. Mycale acerata and $H$. fimbriatus contributed the most biomass to the Hut Point cages (Table 4).

\section{Table 3 and 4 near here}

While many species in Tables 3 and 4 are familiar from the earlier years (T. leptoderma, $H$. fimbriatus, $H$. scotti, $H$. dancoi, $K$. variolosa, etc.), many were species we have never seen despite decades of study in the area. Some are small and inconspicuous; however, I. abnormale, K. coulmani, "Pipe Sponge”, "Cucumber", "Golf Tee” and "Hairy Cucumber" were remarkably abundant on the cages and other surfaces and may represent an episodic recruitment event much like $H$. balfourensis in the 1970s. An nMDS analysis contrasting the sponge species count data on the cages at Cape Armitage and Hut Point is in Supplement A where an ANOSIM analysis found the differences between Hut Point and Cape Armitage at $\mathrm{p}<0.001$.

Assuming that two-dimensional space is the most important limiting resource for sessile encrusting animals, the amount of occupied space gives an estimate of potential space dominance for each species (Table 5). For example, at Cape Armitage, the two Haliclona species occupied a mean of $4 \%$ of the space, but only about $1.5 \%$ at Hut Point. In places they would appear to dominate the space, but we know from previous work that M. acerata (also a mean of 3-4\%) 
overgrows and kills the Haliclona species (Dayton et al., 1974). On the other hand, the very small I.abnormale dominates very little space but is like a vine and overgrows the other speciesso is not likely to be affected by competition for space. The Cape Armitage cages show $R$. podagrosa also has a mean percent cover of about $4 \%$. So while these sponges can be conspicuous and appear to dominate space on the cages, on average they control a small fraction of the available space on the cages.

\section{Table 5 near here}

The percent sponge cover on Cape Armitage cages was more than twice as great as on Hut Point cages, but the total percent cover of the non-sponge species for the two areas are remarkably similar. While the two areas are different, the non-sponge species occupy over four times as much space as do the sponges. However, only about $50 \%$ of the cage surfaces were occupied by sessile organisms, therefore we conclude that simple primary space was not limiting the populations in 2010. It is important to note that this refers to simple exploitative competition for space; however, there could still be important interference competition by impeding settling larvae, especially with the Hydrozoa that are likely to consume larvae. Antifouling defenses are another form of interference competition; sponges and some Bryozoa have chemical or physical defenses with avicularia/vibracula against settlement. In some cases the chemicals diffuse into the water and may reduce settlement near the primary space occupant. For more details regarding cages, see Supplement A. 
Table 3.Density, percent cover, and biomass estimates of 12 cages at Cape Armitage in 2010. * Biomass was not estimated for $R$. podagrosadue to the fact that it is difficult to visualize and measure individual buds of the sponge as would be needed for the calculation. + This category was assigned to tightly intertwined patches of Hydrozoa and Bryozoa that could not be individually identified from the photographs. A dash (-) indicates the species was not found in that treatment. na $=$ not applicable.

\section{Cape Armitage Cages ( $\mathrm{N}=12)$}

\begin{tabular}{|c|c|c|c|c|c|c|}
\hline \multirow[t]{2}{*}{ Identification } & \multicolumn{2}{|c|}{$\begin{array}{l}\text { Total Count } \\
\text { (Whole Cage) }\end{array}$} & \multicolumn{2}{|c|}{$\begin{array}{l}\text { Total Count } \\
\text { (Top Only) }\end{array}$} & $\begin{array}{l}\text { Percent } \\
\text { Cover } \\
\text { (Whole } \\
\text { Cage) }\end{array}$ & \multirow{2}{*}{$\begin{array}{c}\text { Estimated } \\
\text { Biomass (g) } \\
\text { (Whole } \\
\text { Cage) } \\
\text { Mean }\end{array}$} \\
\hline & Total & Mean & Total & Mean & Mean & \\
\hline TetillaleptodermaI & 7 & 0.58 & 0 & 0 & 0.23 & 731.32 \\
\hline Homaxinellabalfourensis & 1 & 0.08 & 0 & 0 & 0.01 & 21.55 \\
\hline Chimney & 2 & 0.17 & 2 & 0.17 & 0.05 & 14.00 \\
\hline Polymastiainvaginata & - & - & - & - & - & - \\
\hline Kirkpatrickiacoulmani & 4 & 0.33 & 3 & 0.25 & 0.14 & 6.22 \\
\hline Cucumber & 9 & 0.75 & 4 & 0.33 & 0.01 & 7.43 \\
\hline Cinachyrabarbata & 1 & 0.08 & 0 & 0 & 0.04 & 37.30 \\
\hline Haliclonascotti & 80 & 6.67 & 39 & 3.25 & 3.52 & 749.95 \\
\hline Pipe & 120 & 10 & 67 & 5.58 & 0.1 & 22.34 \\
\hline Golf Tee & 7 & 0.58 & 3 & 0.25 & 0.01 & 1.00 \\
\hline Suberitessp. & 1 & 0.08 & 1 & 0.08 & 0.02 & 6.32 \\
\hline Hairy Cucumber & 19 & 1.58 & 2 & 0.17 & 0.03 & 21.65 \\
\hline Inflatella belli & 6 & 0.5 & 0 & 0 & 0.05 & 13.57 \\
\hline Stylochordylachupachups & 1 & 0.08 & 1 & 0.08 & 0 & 3.75 \\
\hline Calyx shackeltoni & 1 & 0.08 & 1 & 0.08 & 0.01 & 0.80 \\
\hline Kirkpatrickiavariolosa & - & - & - & - & - & - \\
\hline Rossellapodagrosa & 35 & 2.92 & 2 & 0.17 & 3.64 & $*$ \\
\hline Leucascusleptoraphis & 24 & 2 & 17 & 1.42 & 0.64 & 157.39 \\
\hline
\end{tabular}




\begin{tabular}{|c|c|c|c|c|c|c|}
\hline Iophonabnormale & 256 & 21.33 & 176 & 14.67 & 0.41 & 42.69 \\
\hline Mycale acerata & 24 & 2 & 12 & 1 & 2.97 & 3935.19 \\
\hline Haliclonadancoi & 85 & 7.08 & 41 & 3.42 & 0.25 & 39.00 \\
\hline Cinachyraantarctica & 10 & 0.83 & 0 & 0 & 0.17 & 47.71 \\
\hline Hemigelliusfimbriatus & 14 & 1.17 & 9 & 0.75 & 0.48 & 789.02 \\
\hline Isodictyasetifera & 1 & 0.08 & 1 & 0.08 & 0.05 & 60.00 \\
\hline Sphaerlotylusantarcticus & - & - & - & - & - & - \\
\hline Unknown White & 1 & 0.08 & 1 & 0.08 & 0.01 & 0.00 \\
\hline White Tube Finger & 1 & 0.08 & 0 & 0 & 0 & 0.26 \\
\hline Alcyoniumantarcticum & 293 & 24.42 & 133 & 11.08 & 1.57 & na \\
\hline Hornerasp. & 17 & 1.42 & 3 & 0.25 & 0.82 & na \\
\hline Reteporellasp. & 15 & 1.25 & 5 & 0.42 & 0.11 & na \\
\hline Orange Mushroom & - & - & - & - & - & - \\
\hline Oyster Mushroom & 95 & 7.92 & 17 & 1.42 & 1.87 & na \\
\hline Camptoplitessp. & 20 & 1.67 & 1 & 0.08 & 0.05 & na \\
\hline Hornerasp. & 493 & 41.08 & 236 & 19.67 & 1.57 & na \\
\hline Hydrodendronaboreum & 7 & 0.58 & 3 & 0.25 & 1.69 & na \\
\hline Hydrozoa/Bryozoa Patches+ & na & na & na & na & 35.14 & na \\
\hline Corymorphamicrorhiza & 1 & 0.08 & 1 & 0.08 & 0.27 & na \\
\hline Zyzzyzusparvula & 1 & 0.08 & 1 & 0.08 & 0.31 & na \\
\hline
\end{tabular}


Table4.Density, percent cover, and biomass estimates of 12 cages at Hut Point. * Biomass was not estimated for $R$. podagrosadue to the fact that it is difficult to visualize and measure individual buds of the sponge. + This category was assigned to tightly intertwined patches of Hydrozoa and Bryozoa that could not be individually identified from the photographs. A dash (-) indicates the species was not found in that treatment.

\begin{tabular}{|c|c|c|c|c|c|c|}
\hline \multicolumn{7}{|c|}{ Hut Point Cages $(\mathrm{N}=8)$} \\
\hline \multirow[t]{2}{*}{ Identification } & \multicolumn{2}{|c|}{$\begin{array}{l}\text { Total Count } \\
\text { (Whole Cage) }\end{array}$} & \multicolumn{2}{|c|}{$\begin{array}{l}\text { Total Count } \\
\text { (Top Only) }\end{array}$} & \multirow{2}{*}{$\begin{array}{c}\text { Percent } \\
\text { Cover } \\
\text { (All/Whole } \\
\text { Cages) } \\
\text { Mean }\end{array}$} & \multirow{2}{*}{$\begin{array}{c}\text { Biomass (g) } \\
\text { (All/ Whole } \\
\text { Cage) } \\
\text { Mean }\end{array}$} \\
\hline & Total & Mean & Total & Mean & & \\
\hline TetillaleptodermaI & 3 & 0.38 & 1 & 0.13 & 0.14 & 2.21 \\
\hline Homaxinellabalfourensis & - & - & - & - & - & - \\
\hline Chimney & 2 & 0.25 & 1 & 0.13 & 0.04 & 11.08 \\
\hline Polymastiainvaginata & 3 & 0.38 & 0 & 0.00 & 0.00 & 0.13 \\
\hline Kirkpatrickiacoulmani & 4 & 0.50 & 2 & 0.25 & 0.07 & 8.02 \\
\hline Cucumber & 16 & 2.00 & 1 & 0.13 & 0.02 & 33.58 \\
\hline Cinachyrabarbata & - & - & - & - & - & - \\
\hline Haliclonascotti & 53 & 6.63 & 32 & 4.00 & 1.20 & 272.23 \\
\hline Pipe & 128 & 16.00 & 18 & 2.25 & 0.04 & 65.77 \\
\hline Golf Tee & - & - & - & - & - & - \\
\hline Suberitessp. & 3 & 0.38 & 1 & 0.13 & 0.06 & 18.13 \\
\hline Hairy Cucumber & 44 & 5.50 & 0 & 0.00 & 0.07 & 108.79 \\
\hline Inflatella belli & 26 & 3.25 & 0 & 0.00 & 0.30 & 92.35 \\
\hline Stylochordylachupachups & - & - & - & - & - & - \\
\hline Calyx shakeltoni & 1 & 0.13 & 1 & 0.13 & 0.01 & 7.17 \\
\hline Kirkpatrickiavariolosa & 2 & 0.25 & 2 & 0.25 & 0.02 & 6.23 \\
\hline Rossellapodagrosa & 8 & 1.00 & 0 & 0.00 & 0.65 & $*$ \\
\hline Leucascusleptoraphis & 11 & 1.38 & 5 & 0.63 & 0.40 & 204.85 \\
\hline Iophonabnormale & 11 & 1.38 & 2 & 0.25 & 0.02 & 2.02 \\
\hline
\end{tabular}




\begin{tabular}{lcccccc} 
Mycale acerata & 7 & 0.88 & 6 & 0.75 & 1.05 & 2961.63 \\
Haliclonadancoi & 57 & 7.13 & 5 & 0.63 & 0.07 & 8.68 \\
Cinachyraantarctica & 4 & 0.50 & 0 & 0.00 & 0.02 & 1.24 \\
Hemigelliusfimbriatus & 81 & 10.13 & 22 & 2.75 & 0.74 & 1025.90 \\
Isodictyasetifera & 2 & 0.25 & 0 & 0.00 & 0.02 & 15.99 \\
Sphaerlotylusantarcticus & 1 & 0.13 & 0 & 0.00 & 0.04 & 28.18 \\
Unknown White & 3 & 0.38 & 0 & 0.00 & 0.02 & 0.65 \\
\hline Alcyoniumantarcticum & 163 & 20.38 & 16 & 2.00 & 0.37 & na \\
Hornerasp. & - & - & - & - & - & - \\
Reteporellasp. & 13 & 1.63 & 4 & 0.50 & 0.10 & na \\
Orange Mushroom & 230 & 28.75 & 1 & 0.13 & 1.00 & na \\
Oyster Mushroom & 279 & 34.88 & 28 & 3.50 & 7.90 & na \\
Camptoplitessp. & 30 & 3.75 & 9 & 1.13 & 0.63 & na \\
Hornerasp. & 43 & 5.38 & 1 & 0.13 & 0.16 & na \\
Hydrodendron & 27 & 3.38 & 11 & 1.38 & 6.23 & na \\
Hydrozoa/Bryozoa Patches + & - & - & - & - & 20.61 & na \\
\hline & & & & & & \\
\hline
\end{tabular}

Table 5. Comparison of space occupancy (percent cover) by sponges and other invertebrates and invertebrate assemblages on cages at Cape Armitage and Hut Point.

\begin{tabular}{lcc}
\hline & $\begin{array}{c}\text { Cape Armitage } \\
\text { Percent Cover }\end{array}$ & $\begin{array}{c}\text { Hut Point } \\
\text { Percent Cover }\end{array}$ \\
\hline Mean Sponge Cover & $\mathbf{1 2 . 0}$ & $\mathbf{5 . 0}$ \\
\hline Mean Non-sponge Cover & $\mathbf{4 1 . 8}$ & $\mathbf{4 6 . 8}$ \\
$\quad 34.1$ & 20.6 \\
$\quad$ Mixed Bryozoa and Hydrozoa & 4.4 & 19.6 \\
Hydrodendronarboreum & 1.7 & 6.2 \\
Alcyoniumantarcticum & 1.6 & 0.4 \\
\hline Mean Total Invertebrate Cover & $\mathbf{5 3 . 8}$ & $\mathbf{5 1 . 8}$ \\
\hline
\end{tabular}




\subsubsection{Hut Point Washbasin Array}

There was no settlement on the washbasin arrayin 1974 and 1977 (see photos and additional details in Supplement A), but by 2003 the edges of the bowls and the metal frame had a few specimens of the large hydroid $H$. arboretum and the tunicate $C$. verrucosa, the soft coral $A$. antarcticum as well as the sponges $M$. acerata, H. scotti, H. dancoi, D. antarctica, K. coulmani, K. variolosa, Haliclonasp., L. leptoraphis, and at the base of the frame three A. joubini. By 2010 the same species covered the rack, although in many cases individuals had died and been replaced. There was a heavy presence of large specimens of the hydroid H. arboretum that appeared to serve as a nursery for many other invertebrates including several species of anemones, Lyroctiesflavopallidus, holothurians, and Bryozoa as well as abundant colonies of $A$. antarcticum. In addition, three Rossella species ( $R$. podagrosa, $R$. antarctica and $R$. levis) had appeared, as well as more demosponges including Pink Hemigelliussp.Despite the heavy invertebrate settlement around them, the sediment left in the basins in 1977 was devoid of macrofaunalrecruitment in 2010.

\subsubsection{Hut Point Rack}

A single rack of settlement experiments was established at Hut Point in 1974 and recovered in 2010. The racks differ from the other structures because they stand about a meter off the bottom and were composed of settling experiments of plastic freezer cartons containing sediment. In 2010 this single surviving east sound rack was covered with thick growths of many species of Bryozoa but only three sponges (see Supplement A).

\subsubsection{Gangplank}

The large wooden gangplank dropped in 1961 north of Hut Point had no sponges and virtually no megafauna between 1967-68. During a population explosion of the mid-1970s the gangplank accumulated almost 100 percent cover of $H$. balfourensis, but as a result of anchor ice uplifting all the sponges, the structure was virtually bare in 1989 (Figure 3). The gangplank was next observed in 2004 when it was covered with very large A. joubini, one calcareous sponge and 
10species of demosponges that persisted through 2010. By 2010 we estimated that the $A$. joubinihad grown 30-40\% in those six years and the total weight was about $560 \mathrm{~kg}$ or half a metric ton, with a mean weight of $29 \mathrm{~kg}$ (see Figure 4with the estimated weights of A. joubini and 10 demosponge species).

\section{Figure 3 near here}

\section{Figure 4 near here}

Supplement A discusses information gleaned from photographs by Rob Robson and Steve Rupp in 2015. The 2015 photos show some sponges (at least three A. joubiniand several $H$. fimbriatusand Haliclonaspp.) to be missing in 2015 without the characteristic piles of spicules normally characterizing dead sponges, suggesting that they were removed by anchor ice.

The 2015 photos (Supplement A) also appear to show that the large A. joubini are smaller and sometimes caved inwards, suggesting that they were dying. If this is true, the cause of the mortality is not known although Dayton et al. (2013) observed that they were infested with the amphipod, Sebaantarcticaand were being consumed by Acodontasterspp. Because the gangplank is conspicuous and easily accessible from McMurdo Station, we hope that these photographs encourage repeat future visits to this structure that offers so much ecological insight.

\subsubsection{The Weasel}

The Weasel was first observed in 1989, and it supported a diverse group of sponges including eleven A. joubini ranging in size from 38.7 to $86798.9 \mathrm{~cm}^{3}$ (see photo in Supplement A). These tagged individuals had increased in size by 0.02 to $16 \%$ when they were re-examined four years later. Seven additional recruits to the Weasel, identified in 1993 (thus representing no more than 4 years of actual growth) ranged in size from 4.5 to $43.9 \mathrm{~cm}^{3}$. While there were no new recruits in 1994 , the seven sponges had increased in size by 13.5 to $23.7 \%$ in a single year. Relative percent changes in annual growth rates of these sponges between 1989 and 2004 indicate that small individuals $\left(<50 \mathrm{~cm}^{3}\right)$ undergo the greatest change in biomass, while the largest 
individuals $\left(>8000 \mathrm{~cm}^{3}\right)$ have essentially stopped growing. See Supplement A for more information.

\subsubsection{Casing}

No recruitment was observed on the outside or inside of the casing from 1961, when it was dropped to the bottom, through 1968. By late 1977, a few Hydrozoa, Bryozoa and A. antarcticum appeared on the inside (Figure 5). There still were no sponges by 1989, but there was a heavy settlement of Hydrozoa, especially $H$. arboretum, the solitary tunicate $C$. verrucosa, the soft coral A. antarcticum, and many species of Bryozoa. When we returned in 2010 the invertebrates had grown and there were scattered $H$. scotti inside the casing, some of which were large enough to have settled as early as 2000. In addition there were two R.antarctica, and they too had increased their mass by an estimated 30\% between 2010 and 2012. While photos from each end were evaluated for the total of sponge species in 2010, a large number of high-resolution photos were taken in 2012 by Andrew Thurber and a careful evaluation of species along the exterior interface of the casing with the sponge spicule mat found a total of 8 species that appeared to be on the casing.

\section{Figure 5 near here}

\subsubsection{Pipe cages}

The large pipe cages followed the same pattern of no sponge recruitment from the 1960s through the 1980s with the exception of $H$. balfourensis in the 1970s, but in 2010 were found heavily encrusted with many species of invertebrates. See Supplement Afor photos and discussion.

\subsubsection{Cape Armitage Floaters}

The floating arrays of settlement surfaces at Cape Armitage had H. arboretum, scattered serpulid polychaetes, and a few H. balfourensis through the 1970s. By 1989 floaters suspended at $60 \mathrm{~m}$ at Cape Armitage where heavily colonized in patches along the lines and on the 
settlement surfaces by $H$. arboretum, C. verrucosa, dense aggregations of $H$. balfourensis and scattered individuals of $H$. dancoi, I. setifera and the soft coral A. antarcticum. There were also scattered clusters of the Hydrozoa C. parvula and C. microrhiza along the lines. These observations are important because they place the larvae of these species in the water column in the 1980s.

In 1998 Kathy Conlan photographed a floater on which the settling surfaces were covered with $H$. balfourensis, C. verrucosa and C. microrhiza (see Supplement A). By 2010 the floaters at Cape Armitage had so much material on them that they were sinking. They were covered with many species of Hydrozoa and Bryozoa as well as dense associations of the sponges $H$. balfourensis, M. acerata, "Pipe Sponge", "White Tube Finger", "Hairy Cucumber", I. setifera, and a few unknown demosponge and calcareous sponges (see Supplement A).

\subsection{West Side, Explorers Cove, New Harbour 1974 - 2010}

The entire ecosystem including the structures and recruitment patterns at Explorers Cove in New Harbour on the west side of McMurdo Sound was substantially different from Hut Point and Cape Armitage.Here the softsediments are very different from the spicule mat and hard igneous rock of the east side, and support many species of metazoan predators, especially polychaetes, amphipods, ophiuroids, asteroids, echinoids, fish, and pycnogonids. In addition there are high densities of agglutinated foraminifera (Suhret al., 2008). There are few freestanding sponges, but in the beginning we never considered this to be a sponge habitat, and our research focused on understanding the dynamics of the soft bottom community (Dayton and Oliver, 1977).The Explorers Cove sites were at three depths, 24, 37, and $43 \mathrm{~m}$ (see Figure 1). An analysis of the species recruiting on the structures demonstrate a different composition of species between the east and west sides of the sound (see Supplement A).

\subsubsection{Explorers Cove Washbasin Arrays}

Several washbasin arraysfor soft sediment experiments were established in 1974 at Explorers Cove.Two sets of racks at $37 \mathrm{~m}$ depth had large washbasins on solid plastic structures supported 
about $25 \mathrm{~cm}$ off the bottom. The soft sediment in the bowls never experienced sponge recruitment, but the edges of the bowls had small recruits of two species in 2004 and a few more species settled on this habitat by 2010. In particular, there were two species (D. antarctica and $K$. coulmani) in 2004 and in 2010, but they were relatively small (Figure 6A, top panel).

Interestingly, another pair of washbasinsas in the $24 \mathrm{~m}$ site had considerable recruitment as seen by poor quality photographs taken in 1975, 1989, and 2004.There were many large A.joubinias well as several other species on the racks and edges of the basins, but no sponges were observed in the sediment inside the washbasins (Figure 6B top panel).

\section{Figure 6 near here}

\subsubsection{Explorers Cove Racks}

Racks were set 1.0 to $1.3 \mathrm{~m}$ off the bottom (at 24 and 37m depth) in 1974 (see Figure 6, bottom panel). By 1985 - 1989 the racks had accumulated scattered Hydrozoa, especially H. arboretum, several species of Bryozoa and relatively dense settlements of $H$. balfourensis. One rack was visited 15 years later in 2004 when the structure was conspicuous for at least four very large $A$. joubini and a large R. fibulata and D. antarctica and a scattering of $H$. dancoi. The 2010 photo from the opposite side (Figure 6E bottom panel) shows that the A. joubinihad grown large enough to push at least two sponges off the rack leaving it covered with a very diverse association of mostly unidentified sponges, Hydrozoa, tube building polychaetes and Bryozoa. Many of the 17 sponge species observed on the racks have not been identified and there are no vouchers for most of them. Supplement Adiscusses each of the sponges with as much detail as is available.The rare Rossellafibulata growing from the bottom of the rack in 2004 was approximately $20 \mathrm{~cm}$ in diameter, and it grew about $25 \%$ by 2010 . The $2010 \mathrm{~A}$. joubini varied in size from approximately $16-60 \mathrm{~cm}$ in diameter and were large enough to push each other off the racks (see Figure 4 in Dayton et al., 2013).

\subsubsection{Explorers Cove Floaters}


The Explorers Covefloaters were placed at depths of $24-30 \mathrm{~m}, 37$ and $43 \mathrm{~m}$ in Explorers Cove. The floats were at various heights from 15-30 $\mathrm{m}$ above the bottom (Figure 7). These floaters were not disturbed by other divers or anchor ice and offer some of the most interesting observations of the episodic sponge recruitment. Despite the heavy settlement of $H$. balfourensis on the east side through the 1970s, the only settlement we observed through 1970s on any of the surfaces at Explorers Cove were a few serpulid polychaetes on plates suspendedbeneath floats. Paradoxically, the oceanographic shifts that resulted in the heavy anchor ice formation during the 1980s on the east side were correlated with increased settlement on thesurfaces and floating structures at the oligotrophic Explorers Cove site. By 1984 the settling surfaces in Explorers Cove had several species of Bryozoa and Hydrozoa, and a few soft corals; by 1989 most of the settling surfaces were completely covered with Hydrozoa, Bryozoa, ascidians, some soft corals and a few clusters of $H$. scotti, $H$. dancoi, $M$. acerata and dense settlements of $H$. balfourensis, the only sponge species observed to settle in Explorers Cove through 1989 with the exception of two small A. joubini high up on a floater in 1989 (Dayton, 1989). In 2004 the floaters in Explorers Cove had D.antarctica, M. acerata, H. scotti, H. dancoi, "Pipe Sponge" and conspicuous A. joubini. At that time some A. joubini had grown to 50 cmdiameter and some of floaters were sinking under their weight. Six years later (in 2010) all these species were on most of the floaters, and the A. joubini had grown to such large sizes that their weight had sunk or was sinking the floaters to the bottom(See Supplement A). Almost all of the A. joubini and othersponges that had fallen to the bottom were dead, possibly choked with sediment or consumed by predators such as Acodontaster conspicuous, Saba sp. and possibly the urchin Sterechinusneumayeri and the pencil urchin, Ctenocidarisperrieri, all of which have been observed eating sponges (Dayton, pers. obs.).

One large floating structure at the $24 \mathrm{~m}$ site was established in 1975 some $15 \mathrm{~m}$ above the bottom holding experiments with sediment (Figure 7, bottom panel). The structure was left floating when the experiments were retrieved, and by 1989 it had a heavy cover of $H$. balfourensis and perhaps a couple Haliclona spp. These photographs showed that the two very small A. joubini observed on the large floating array 11 years earlier had become so large by 2003 that the floating array was almost sunk and was just a few meters off the bottom. By 2004 it was touching the bottom, had tipped on its side and dumped the two large sponges to the seafloor. 
The fact that the sponges on the seafloor were still alive in 2004 suggests that they had been dumped recently. By 2004 there was growth of the A. joubini still attached to the floater, but they were falling off it. By 2010 all the sponges were dead on the seafloor and the bare rack had floated back up in the water column on its side.

\section{Figure 7 near here}

Four floaters were carefully analyzed for density and estimated biomass of the 14 species of sponges that were found in 2010 (Table 6). The sponges settled relatively evenly on the floating lines, with many species on the floatsthemselves. The ephemeral H.balfourensis was by far the most abundant recruit with over 33 per meter of line. The unidentified "White Tube Finger", D.antarctica, and the unidentified "Pipe Sponge" were the next most abundant. There was a remarkably dense recruitment of $A$. joubini that had grown very large, over $342 \mathrm{~kg}$ total, many large enough that they had fallen off the floater. Because of their weight, all of the floaters had sunk (see Supplement A).

\section{Table 6 near here}

This level of recruitment is remarkable as the general area has very few sponges to provide a source of propagules, and the racks and floaters had virtually no sponges from 1974 through 1989 with the exception of the few opportunistic species. In contrast with the 14 species of sponges found on the Explorer Cove floaters, the Cape Armitage floaters examined had only the following six species of sponges: Homaxinellabalfourensis, "Pipe Sponge”, "White TubeFinger", “Hairy Cucumber", I.setifera, and an "Unknown White”demosponge. 
Table 6. Counts, density, size and biomass of sponges on Explorers Cove floaters.

\begin{tabular}{lcccc}
\hline \multicolumn{4}{c}{ Explorers Cove Floaters (N=4) } & \\
\hline Identification & $\begin{array}{c}\text { Total } \\
\text { Count }\end{array}$ & $\begin{array}{c}\text { Density } \\
\text { (Number } \\
\text { individuals/meter } \\
\text { rope) }\end{array}$ & $\begin{array}{c}\text { Mean } \\
\text { Length/Diameter } \\
\text { (cm) }\end{array}$ & $\begin{array}{c}\text { Total } \\
\text { Biomass } \\
\text { (g) }\end{array}$ \\
\hline Homaxinellabalfourensis & 1482 & 33.32 & 6.23 & 3573 \\
Dendrillaantarctica & 83 & 1.99 & 10.93 & 832 \\
Cottonball & 9 & 0.17 & 1.05 & 6 \\
Dandelion & 1 & 0.05 & 2.71 & 70 \\
Microxina sp. & 2 & 0.04 & 2.80 & 14 \\
Pipe & 58 & 1.19 & 3.44 & 125 \\
Leucascusleptoraphis & 1 & 0.02 & 1.23 & 4 \\
Mycale acerata & 2 & 0.04 & 1.41 & 38 \\
Isodictyasetifera & 7 & 0.16 & 9.15 & 991 \\
Unknown Pink & 1 & 0.03 & 5.37 & 31 \\
Unknown White & 8 & 0.19 & 3.66 & 9 \\
Anoxycalyxjoubini & 26 & 0.61 & 21.75 & 34214 \\
White Tube Finger & 398 & 9.47 & 4.11 & 314 \\
\hline
\end{tabular}

We could not identify nor measure the non-sponge species that settled on the floaters, but we did estimate their percent cover (Table 7). Not surprisingly, Hydrozoa and Bryozoa occupy over $80 \%$ of the area in the photographs. Most were utilizing secondary space, so this is not indicative of competition for space, but we do speculate that the high density of feeding zooids must influence the abundance and distribution of larvae settling on the surfaces below the Hydrozoa.

\section{Table 7 near here}

A table summarizing the relative densities of the various species settling on the all the structures can be seen in Supplement A. An nMDS analysis of presence - absence assemblages exhibited significant differences between the east and west sides of the sound $(p<0.001)$ (see Supplement A). 
Table 7. Estimates of percent cover of major non-sponge phyla on Explorers Cove floaters. Explorers Cove Floaters $(\mathrm{N}=4)$

\begin{tabular}{cc}
\hline Non-Sponge Phyla & Est. Percent Cover \\
\hline Hydrozoa & $60 \%$ \\
Bryozoa & $25 \%$ \\
Anthozoa & $<10 \%$ \\
\hline
\end{tabular}

\section{Discussion}

4.1 Key result:Episodic recruitment: 30 years in stasis then extreme change

These long-term observations provide a unique insight into the dynamics of Antarctic coastal ecosystems.For over 30 years (1967-2000), poor recruitment and slow growth of sponges in the extremely consistent and cold water contributed to the paradigm of slow ecological processes in Antarctic waters. With only a 10-year extension to our time series (2000-2010),we observed massive settlement of a diverse array of sponges on both sides of McMurdo Sound and for some,remarkably fast growth. The Antarctic benthic ecosystem, isolated for some 34 million years, is often considered to reflect the ecology of the Cretaceous, characterized by very small calcareous nanoplankton and dinoflagellates, sponges and slow moving predators, especially echinoderms (Gili et al., 2006). But climate change appears to be opening this time capsule and recent climate-induced changes have offered some improved understanding of Antarctic community dynamics and succession (Gutt et al., 2011, Fillingeret. al, 2013, Torre et al., 2012, Barnes et al., 2014). Obviously, only long-term data, complimented by environmental and natural history information, can hope to reveal changes in ecosystems driven by infrequent events. These events have the potential to influence ecological structure and function for future decades, and also to provide opportunities to better understand how the seafloor ecosystems will respond to change.

A striking episodic recruitment event in McMurdo Sound involved a massive settlement of the opportunistic sponge H.balfourensis during the 1970s (Dayton, 1989). However, that event affected only the one species of sponge in a very localized area, associated with changes in the 
anchor ice disturbance regime. Given there had been virtually no such settlement for the preceding three decades, we can draw on a number of lines of evidence as to what environmental factors were responsible for the much more pervasive sudden recruitment and growth in the late 1990s and 2000s. The multi-species settlement reported here happened during periods of heavy sea ice cover. Persistent multi-year ice would protect the coast from wave disturbance and resuspension and transport of propagules or sponge fragments, enhancing localized recruitment.

\section{2 EnvironmentalDrivers That Potentially Coincide With Time SeriesChanges}

\subsubsection{IcebergBlocking}

Accounting for any episodic event in ecological data is most simply explained in terms of a single controlling environmental driver that is co-incident with, or coherently lagged to, ecological change. Given the diversity of sponge species observed from 2000 on both the east and west sides of McMurdo Sound we might surmise that a large-scale factor influencing coastal oceanography and food supply is responsible. The most obvious change in the local oceanography around 2000 relates to the massive icebergs that broke off the Ross Ice Shelf and grounded just north of McMurdo Sound,restricting sea ice breakout and production in the Ross Sea polyna and changing flow and connectivity between the sound and the Ross Sea (Thrush and Cummings, 2011). In particular, this event restricted the seasonal plankton bloom of Phaeocystis, a large and aggregating phytoplankton. This and otherlarge chain forming diatoms are usually advected southward into McMurdo Sound along the Ross Island coast (Littlepage, 1965, Barry, 1988). One implication of such a blockage would be a shift in the food regime for sponges from that of Phaeocystisand diatoms that most sponges cannot consume to one of bacteria and microplankton that stimulates the growth of sponges (Montes-Hugo et al., 2009, Reiswig 1990, Thurber, 2007, Yahel et al., 2006,Orejas et al., 2000).

While the iceberg-blocking hypothesis is attractive, it is considerably weakened by observations of the settlement before the iceberg broke off the Ross Ice Shelf.In this case the settlement of 12 species of sponges in the early 1990s on the caged substrata (Table 2) is indication that the beginning of the settlement pre-dated the iceberg blockage.Furthermore, the large size of 
sponges seen on the structures in Explorers Cove in 2002 and 2004 also argue that the settlement event started before the icebergs blocked McMurdo Sound about 2000.

\subsubsection{Oceanographic Changes}

Other potential large-scale environmental drivers includelarge-scale oceanographic processes such as the Pacific Decadal Oscillation (PDO).Geostrophic and various aperiodic forcing functions such as the East Wind Drift reflect large-scale atmospheric and oceanographic dynamics that have variable long-term variation (Dayton, 1989).Barry and Dayton (1988) speculated that changes in zonal winds associated with the 1982-83 ENSO event might have been responsible for the strong northerly flows in McMurdo Sound during the 1980s.Li et al. (2015) found connections between ENSOs and PDOs in the ice records and suggested the existence of teleconnections from the PDO to McMurdo Sound. There was a large PDO in the late 1990 s that correlates nicely with our observations.

\subsubsection{Terrigeneous and Iceberg Nutrients}

Land-coast interactions are rarely considered in the Antarctic, but with climate change they too very likely contribute to ecological processes in the coastal zone. Mikucki et al.(2015) report large amounts of deep ground water moving through the Dry Valleys into lakes and the sea.In addition to terrigeneous nutrients, Dupratet al. (2016) report large-scale fertilization by large icebergs. These flooding events from glacial meltwater, andthe break up of the Ross Ice Shelf in the 2000 s,potentially releases iron and other nutrients that locally fertilize coastal waters (Duprat et al., 2016,Dayton et al., in press, Kim et al., unpublished results). The almost order of magnitude reduction in maximum visibility from a measured $290 \mathrm{~m}$ in 1967 and 1992 to under $60 \mathrm{~m}$ by 2014 at McMurdo Station (Table 1)may be a consequence of a major oceanographic change. This hypothesized nutrient pulse in the dark conditions below thick sea ice is most likely to result in blooms of microphytoplankton that alone could be responsible for the population explosions of so many species of sponges. Especially noteworthy is the timing of the very large flood events with attendant sea ice melting in 2001 (Doran et al., 2008), just about the same date as the estimated settlement and growth occurred. 


\subsubsection{Processes of Recruitment}

Theseobservations are the emergent product of cumulative factors including the alignment of different recruitment bottlenecks and environmental filters. These time-series observations integrate the effects of dispersal, settlement, early survivorship, and growth. A distinct sequence of events must occur to observe large sponges on our settlement structures. First, competent propagules need to be available in the environment; second, they need to disperse to the habitat in question; third, they need to settle and metamorphose, and fourth, they need to survive long enough to be photographed. These phenomena are poorly studied for sponges in any environment, let alone the Antarctic. The observed changes are dramatic, andthe temporal resolution of the time series does not allow the detection or interpretation of subtle consequences of species-specific effects. However, the potential for a time-dependent regime shift in the distribution and abundance of foundation species provides important insight into how these dynamics play.

\subsection{Fundamental and Realized Recruitment and Community Resilience}

As well as considering the potential effect of physical drivers of change, this time series also provides insight into the ecosystem response to change.Analogous to the concepts of fundamental and realized niches, our observations of recruitment on elevated artificial surfaces, but not on the adjacent seafloor emphasize differences in fundamental and realized recruitment.Unusual sponge recruitment across McMurdo Sound on artificial surfaces reveals the availability of colonists.But the lack of sponges on the seafloor, particularly in the softsediment environments of Explorers Cove, the sediment inside the washbasins, and the cleaning of artificial surface that sank to the seafloor imply benthic process such as predation and biogenic sediment disturbance and resuspension are limiting the expansion of sponge assemblages.

\subsubsection{Dispersal Biology and Fundamental Recruitment}


A variety of abiotic factors including temperature, flow, light, surface rugosity, and sedimentation influence larval release, dispersal, settlement behaviors, metamorphosis, and/or survival (Thorson, 1966).In general sponges are not considered to disperse very far (Bergquist et al., 1970, Maldonado and Bergquist, 2002), and species with pelagic larvae are relatively rare, suggesting that currents are important dispersal agents. Distinct recruitment patternsas indicated by both the differences and variability in sponge assemblage composition (see Supplement A,)are likely the product of cross-sound and local scale oceanographic variability as well as the variation on sponge cover and diversity in each location.

The presence-absence analysis (Supplement A) shows that the Cape Armitage and Hut Point samples are similar to each other and homogeneous in composition, suggesting similar connectivity and relationships to source pools. The Explorers Cove data are more dispersed, suggesting patchy sources for this community.With regard to the source areas, strong currents and associated turbulence along the east side of the sound can transport propagules some distance, and the two research sites separated by 1-2 km share most species,although their abundances differ.In contrast, the sources of sponge propagules on the west side of McMurdo Sound are very different withspare and patchy sponge associations. The most common species on both sides of the sound were the ubiquitous $H$. balfourensis and small pipe-like sponges believed to be calcareous sponges. Other species with effective dispersal and recruitment onto the structures included Haliclona spp., M. acerata, and I. setifera. Although the sand/mud habitats of New Harbourwere relatively bare of sponges, large healthy specimens of $R$. racovitzae, $R$. levis, $R$. fibulata, $R$. podagrosa, $R$. antarctica, and A. joubini do exist, as do scattered individuals of $D$. antarctica, K. coulmani, $H$. scotti and $H$. dancoi. The sponge species with the most dramatic differences between the two sides of the sound were A. joubini and D.antarctica. Interestingly, Anoxycalyxjoubini almost completely covered the gangplank and a few settled on the Weasel, three settled on the washbasin array at Cape Armitage, two settled on plates at Cape Evans, and one settled inside a pipe cage.But there were many more other east sound structures where A. joubini did not recruit, in spite of the fact that they were relatively common members of the background community. Despite the lower density of adult $A$. joubiniin the west sound, they settled on virtually all of the west sound structures and in great numbers on the highest floaters. This is the largest sponge in the Antarctic, yet it was extremely abundant up 
high on the west sound structures. The smaller D. antarctica is another enigma because it very rarely settled on the east sound, but was relatively abundant on the floaters and other west sound structures.

The sponges that settled on the structures at Hut Point and Cape Armitage are common in their immediate locations implying that many of these species might be dispersed passively in the water column. For species to settle on substrata supported well off the bottom by floats indicates that the propagules occur well off the seafloor, though this does not equate with good swimming ability if there is strong turbulent mixing.It may also be that propagules are in the water column on both sides of the sound but the strong currents on the eastern side of the sound limit settlement and initial attachment.

How does one explain the fact that the east sound sponge propagules experiencing much more dynamic oceanography do not settle on structures in the water column while those at Explorers Cove with virtually no currents and almost always under thick sea ice settle high on the floaters?Given the differences in oceanographic conditions between the east and west sides of McMurdo Sound, it was surprising to see sponges colonizing ropes floating high in the water column. This implies larval behavior isan important component of dispersal.For example, Haliclona spp.are thought to be strongly photophilic (Bergquist and Sinclair, 1968, Leys and Degnan, 2001) which would explain its relatively ubiquitous recruitment. Clearly H. balfourensis appears able to settle in high densities at all levels, but this species is an exceptionally ephemeral highly dispersing species, and we speculate that it has opportunistic recruitment, perhaps followed by rapid asexual propagation. Reiswig (1973) reported Caribbean Mycale to have large motile larvae seemingly similar to those of Mycale acerata. In general, however, such swimming and effective settlement is not common for sponges and is unlikely at least for some species such as the sphirophorids (C. antarcticaand T.leptoderma) that lack the larval stage and rely on nonswimming "bud-like” propagules (Barthel and Gutt, 1992; Maldonado et al., in press;Manuel Maldonado pers.comm.).

Apart from larval behavior, propagules may gain buoyancy from the attachment of ice crystals, although to our knowledge this process has never been reported. Super-cooled seawater forms 
tiny ice crystals in the water column and it is conceivable that these small crystals could nucleate on larvae or small buds, as has been observed for individual polyps of the stoloniferous soft coral Clavulariafrankliniana (M. Slattery, pers. obs.). This could be an important mechanism for uplifting and transporting propagules, and because it would keep them mixed in the water column, it might be a more effective dispersal mechanism onto the floaters at Explorers Cove where the modest currents might allow the propagules to settle, while the much stronger Hut Point and Cape Armitage currents might blow the propagules past the floaters. It is important to note that these inferencesare drawn on dispersal mechanisms from observations on species distributions and theknowledge of oceanographic conditions in McMurdo Sound. In other parts of the Antarctic stratification may be important as it is associated with internal waves, up- or down-welling or surface waves (Barthel and Gutt, 1992).

\subsubsection{Realized Recruitment on Artificial and Natural Substrata}

These observations of recruitment patterns on either side of the sound highlight the fact that postsettlement factors also influence the observed patterns because dispersal and propagule supply alone cannot explain the observations. The species diversity and relative density of settlement on the west sound with extremely slow currents was much higher than on the east sound.Sponges are very rare in the dominant soft-sediment habitat of Explorers Cove despite the colonization onto the artificial substrates and scallop shells. Sponges are sensitive to sedimentation (Sally Leys, pers. comm.), and in soft sediment habitats many species disturb and suspend sediments affecting colonization by other species, and these effects are usually strongest on juvenile life stages.

\subsubsection{Larval Filters Determine Realized Vs. Fundamental Recruitment}

More importantly, littlerealized recruitment was observed onany natural surface even when there was intense fundamental recruitment onto adjacent artificial substrata, demonstrating successful dispersal and settlement. Obviously there were abundant competent propagules yet virtually no recruitment on natural substrata. Clearly realized recruitment was largely determined by the various filters (sensu Thorson, 1966) that influence survivorship through the larval stage and by predators filtering settled larvae (Mileikovsky, 1974,Oliver and Slattery, 1985), by competitors 
controlling resource space, and/or allelopathy (Hill, 1998,KuffnerandPaul, 2004), and possibly by facilitation.

Plates elevated off the bottom and predator exclusion experiments over sponge spicule mats in the 1960s yielded little recruitment in the treatments or the controls (Dayton et al., 1974), however,cage experiments over gravel habitats in the 1990s (reported here) resulted in significantly higher recruitment when protected from echinoderms. We hypothesize that the filters inhibiting recruitment include suspension feeders such as tunicates, Hydrozoa, and Cnidaria that extract larvae from the water column, as well as benthic predators including Foraminifera, flatworms, nemerteans, nematodes, Crustacea, polychaetes, gastropods, holothurians, ophiuroids, asteroids and many other taxa that consume settled and metamorphosed larvae. In addition to predation, when space to settle and grow is limiting, there are other deterrents to recruitment include antifouling defenses that involve chemical and physical deterrents such as bryozoan avicularia/vibracula. Combined, these defenses serve as a strong filter on the survivorship of settled larvae and the growth of juveniles. Obviously some propagules do survive these filters and grow to reproduce on natural surfaces, but we did not see many adjacent to our structures in this study.

The sequential effects of these different environmental and biological filters conspire to allow for massive multispecies recruitment events on artificial structures, andimply major differences in fundamental recruitment and realized recruitment. The observed recruitment on artificial surfaces demonstrates that the propagules have arrived, settled and survived to be identified at these locations, whereas the realized recruitment on natural substrata is very different as it implies that the recruits have survived barriers to realized recruitment that are less important on the artificial structures. The episodic sponge recruitment and growth of some 40 species of sponges over 40 years on artificial substrata demonstrates a great deal about dispersal, recruitment, and growth potential, but this potential is not often realized on natural settings. Thus this paper has described the fundamental recruitment patterns of these sponges through time, but not the realized recruitment where it counts: in a natural setting. So a general understanding depends on both the availability of propagules that we have observed as recruits, and the filters 
(sensu Thorson, 1966) or other mechanisms that prevent the establishment of reproductive adults on natural substrata.

\subsection{Conclusion:Value of Long-term Data, Especially in a Time of Change}

It is important to understand patterns of recruitment in the Antarctic benthic community because the once pristine community is increasingly subject to stress from climate change and fishing. Successional processes provide a framework for integrating multispecies dispersal with the postsettlement processes that lead to diverse and established communities. Most succession literature is based on large species of "habitat formers" or "foundation species" (Dayton, 1972), and Gutt et al. (2015) have reviewed the parallels between terrestrial and "Antarctic marine animal forests" justifying the focus on successional process of the large emergent sponges. On the Antarctic seafloor, sponges have been recognized for their role as foundation species that provide habitat structure and interact with top down control from echinoderm predators (Dayton, 1972).Less well understood are the internal dynamics determining eventual recruitment to reproductive adults. Temporal/spatial scaling and the importance of rare episodic events (Dayton and Tegner, 1984, Hewitt et al., 2007), provide an essential backdrop to determinethe relationships between community resilience and ecological thresholds (Thrush et al. 2009), and the relationship between disturbance and successional processes (Dayton, 1971, Dayton et al., 1999, Thrush and Dayton, 2010).In polar habitats there is limited knowledge of the basic patterns and rates of succession, how they influence the organization of polar ecosystems, and therefore how the process differs from other latitudes (Dayton et al., 1994). Our limited Antarctic knowledge comes from a few studies of iceberg disturbance (Gutt,2001, Peck et al. 1999, Gutt and Piepenburg, 2003, Teixidó et al. 2006, Barnes et al., 2014), glacial melting (Sahade, et al., 2015), and the impacts of human activities. These studies mainly concern sedimentary habitats, and usually involve short periods of observation, months to 1-2 years (except see Conlan et al. 2010). In contrast, there is rather little mechanistic information on succession in polar hard bottom communities or in the unique Antarctic sponge spicule mat community.

These attempts to evaluate benthic successional patterns in McMurdo Sound were based on the integration of past studies with the recent observations.Ecologists hope to generalize their work to better understand the patterns and processes across larger scales than their actual research. For 
example, these observations of realized and fundamental recruitment have important implications in forecasting future change. Predictions of ecological change based solely on environmental drivers, without considering ecosystem responses,may miss ecologically important functional changes or resilience. Ecological speculations are valuable, especially when they are offered with an understanding of their limitations and are focused on tractable future research questions. In this casethere is an urgency to understand the bigger picture because the Ross Sea faces many unknown consequences associated with climate change and fishing. This area is unique because it appears to have had a large productive polyna over the Pennell Bank through the ice ages when other regions were completely covered with ice and glaciers (Thatje et al., 2008, Johnson et al., 2008). This suggests that the Ross Sea toothfish, Dissosticusmawsoni, and the fish-eating Killer Whale, Orcinus orca type C, evolved in this area. We understand the limitations of our observations being restricted to McMurdo Sound, but the Pennell Bank has been studied (drop cameras, grabs and trawls) from the IGY to more recent cruises (Barry et al., 2003). There are so many similarities that the processes discussed here almost certainly are general to the Ross Sea and to a considerable extent to other similar Antarctic habitats (Barthel et al., 1991, Downey et al., 2012,Gili et al., 2001, McClintock et al., 2005,Teixidó et al., 2006,Kersken et al., 2016).

\subsubsection{Ecological Phase Shifts and the Critical Importance of Long-term Monitoring}

This paper describes massive recruitment and growth of some species of sponges, surprising dispersal, and some unexpectedly high mortality rates. Ecological research is especially valuable when it offers new insights into nature that define new questions that efficiently move the field forward. Certainly this research emphatically negates a hypothesis of stasis and slow growth and population changes (Dayton et al., 1974), but its main contribution might be the definition of many unanswered questions that point a critical need for long-term monitoring of both the oceanography and the benthic communities of McMurdo Sound as well as for creative new research programs aimed at understanding the processes such as predation and sedimentation that so effectively filter benthic recruitment. 
Elegant theory on succession and community dynamics needs to be grounded in observations of nature. In systems that can change surprisingly over time, as we have demonstrated for the Antarctic benthos, long-term monitoring is essential. This simple, cheap and routine sampling does not gain traction with funding agencies because it has no end point and is usually seen as not "transformative". Yet the observations reported here and in Dayton et al. (2013) fundamentally transformed our understanding of the dynamics of foundations species in this system. Change is inevitable and results in unexpected consequences; if we are to better assess the risks associated with our impacts on the environment and learn from our mistakes we must develop and employ well designed and cost effective long-term monitoring. Without such a program it will not be possible to know whether this is simply an episodic event reverting back to a previous situation or whether we are on the cusp of a major ecological regime shift that will persist into the foreseeable future.

\section{ACKNOWLEDGMENTS}

This paper is dedicated to the sponge biologists everywhere who have been so generous with their time and wisdom. We hope that you find it interesting.

Gordon Robilliard, John Oliver, and Jim Barry each have spent many seasons at McMurdo Sound on this project and none of this project would have been done without their commitment. Thanks to Jim Mastro for visibility data in 1994. This paper rests on the data collected in 2010 and we acknowledge with thanks the hard work by theSCINI crew: Julie Barber, David Burnett, Jennifer Fisher, Kevin O'Connor, DJ Osborne, Tina Sanders, and Bob Zook.For taxonomic assistance over the years we thank Jerry Bakus,Dagmar Barthol, Pat Bergquist,Christian Goecke, DorteJanussen, Vladimir Koltun, Henry Reiswig, Ole Tendel, and Rob van Soest.For photographic contributions here and the supplements, we thank G. Robilliard, J. Mastro, K. Conlan, R. Robbins, S. Rupp, A. Thurber, J. Fisher, J. Barber, K. O’Connor, Shawn Harper, Adam Marsh, and Bruce Miller.We thank Peter Brueggeman for his support and help over many years. This material is based upon work supported by the National Science Foundation over 40 years. We acknowledge the visionary leadership of G. A. Llano in the 1960s and 1970s and R.L. Marinelli and S. Twombly for recognizing the value of long-term data sets and taking a chance 
on this project with NSF grant ANT-0852064. This paper would not have been written without an NSF EAGER grantPLR-1355533 greatly facilitated by C.D. Amsler.Any opinions, findings, and conclusions or recommendations expressed in this publication are those of the authors and do not necessarily reflect the views of the National Science Foundation.

\section{LITERATURE CITED}

Anderson, M., Gorley, R.N., Clarke, R.K., 2008. PERMANOVA+ for PRIMER: guide to software and statistical methods. PRIMER-E. Plymouth, U.K. 214 pp.

AronsonR.B., Smith, K.E., Vos, S.C., McClintock, J.B., Amsler, M.O., Moksnes, P.-O., Ellis, D.S., Kaeli, J., Singh, H., Bailey, J.W.,Schiferl, J.C., van Woesik, R., Martin, M.A., Steffel, B.V., Deal, M.E., Lazarus, S.M., Havenhand, J.N., Swalethorp, R.,Kjellerup,S. Thatje, S., 2015. No barrier to emergence of bathyal king crabs on the Antarctic shelf. P. Natl. Acad. Sci. USA.112(42), 12997-13002.

Arntz, W.E., Brey T., Gallardo V.A., 1994. Antarctic zoobenthos. Oceanogr. Mar.Bio. Ann. Rev. $32,241-304$.

Barnes, D.K.A., Fenton,M.,Cordingley, A., 2014.Climate-linked iceberg activity massively reduces spatial competition in Antarctic shallow waters. Curr.Biol. 24(12), R553-R554.

Barry, J.P.,1988.Hydrographic patterns in McMurdo Sound, Antarctica and their relationship to local benthic communities.Polar Biol. 8, 377-391.

Barry J.P., Dayton P.K., 1988.Current patterns in McMurdo Sound, Antarctica and their implications for productivity of local benthic communities.Polar Biol. 8, 367-376.

Barry, J.P, Grebmeier, J.M., Smith, J. Dunbar, R.B., 2003. Oceanographic versus seafloorhabitat control of benthic megafaunalcommunities in the S.W. Ross Sea, Antarctica. In Paleobiology and Paleoenvironments of Eocene Rocks.Antar. Res.S. 76,335-347. 
Barthel, D., Gutt, J., 1992. Sponge associations in the eastern Weddell Sea. Antarct.Sci.4(2), 137-150.

Barthel, D., Gutt, J., Tendal, O.S., 1991. New information on the biology of Antarctic deepwater sponges derived from underwater photography. Mar. Ecol. - Prog.Ser. 69, 303-307.

Bergquist, P.R., Sinclair, M.E., 1968. The morphology and behavior of larvae of some intertidal sponges. New Zeal. J. Mar. Fresh.2, 426-437.

Bergquist, P.R., Sinclair, M.E., Hogg, J.J., 1970. Adaptation to intertidal existence: reproductive cycles and larval behavior in Demospongiae. Symp. Zool. Soc. Lond. 25, 247-271.

Bullivant, J.S., Dearborn, J.H., 1967. The Fauna of the Ross Sea, Part 5: general accounts, station lists, and benthic ecology, New Zeal.Oceanogr. Inst. Memoir No. 32. Bull.New Zeal. Dept. Scient.Ind.Res. 176.

Conlan, K.E., Kim, S.L., Thurber, A.R., Hendrycks, E., 2010. Benthic changes atMcMurdo Station, Antarctica following local sewage treatment and regionaliceberg-mediated productivity decline. Mar.Pollut.Bull. 60, 419-432.

Dayton, P.K., 1971. Competition, disturbance, and community organization: the provision and subsequent utilization of space in a rocky intertidal community. Ecol. Monogr. 41 (4), 351-389.

Dayton, P.K.,1972. Toward an understanding of community resilience and the potential effects of enrichment to the benthos at McMurdo Sound, Antarctica, in: Parker, B.C. (Ed.), Proceedings of the Colloquium on Conservation Problems in Antarctica. Allen Press, Kansas, pp. 81-95.

Dayton, P.K., 1979. Observations of growth, dispersal and population dynamics ofsome sponges in McMurdo Sound, Antarctica,in: Levi C., Boury-Esnault,N.(Eds.),ColloquesInternationaux du Centre National de la Recherche'Scientifique. Paris: Biologiedes Spongiaires (Sponge Biology), 271-282. 
Dayton, P.K., 1989.Interdecadal variation in an Antarctic sponge and itspredators from oceanographic climate shifts. Science. 245, 1484-1486.

Dayton P.K., Kim S., Jarrell S.C., Oliver J.S., Hammerstrom K., Fisher, J.L., O’Connor, K., Barber, J.S., Robilliard, G., Barry, J., Thurber, A.R., Conlan, K., 2013.Recruitment, growth and mortality of an Antarctic hexactinellidsponge, Anoxycalyxjoubini.PLoS ONE. 8(2), e56939.doi:10.1371/journal.pone.0056939

Dayton, P.K., Mordida, B.J., Bacon, F.,1994.Polar marine communities.Amer. Zool. 34, 90-99.

Dayton, P.K., Oliver, J.S., 1977. Antarctic soft-bottom benthos in oligotrophic andeutrophic environments. Science. 197, 55-58.

Dayton, P.K., Robilliard, G.A., Paine, R.T., 1970. Benthic faunal zonation as a result of anchor ice at McMurdo Sound, Antarctica, in: Holdgate, M. (Ed), Vol. 1, Antarctic Ecology. Academic Press, London, pp. 244-258.

Dayton, P.K., Robilliard, G.A., Paine, R.T., Dayton, L.B., 1974.Biologicalaccommodation in the benthic community at McMurdo Sound, Antarctica.Ecol.Monogr. 44, 105-128.

Dayton, P.K., Tegner, M.J.,1984. The importance of scale in community ecology: a kelp forest example with terrestrial analogs, in: Price, P.W., Slobodchikoff, C.N., Gaud, W.S. (Eds.), In A New Ecology: Novel Approaches to Interactive Systems. Wiley, New York, pp. 457-481.

Dayton, P.K., Tegner, M.J.,Edwards, P.B., Riser, K.L.,1999. Temporal and spatial scales of kelp demography: the role of oceanographic climate.Ecol. Monogr.69(2), 219-250.

Dayton, P.K., Watson, D., Palmisano, A., Barry, J.P., Oliver, J.S., Rivera, D., 1986.Distribution patterns of benthic microalgae standing stock at McMurdo Sound, Antarctica.Polar Biol. 6, 207213. 
Dearborn, J.H., 1965. Ecological and faunistic investigations of the marine benthos at McMurdo Sound, Antarctica.Doctoral dissertation, Stanford University, California.

Doran, P.T., McKay, C.P., Fountain, A.G., Nylen, T., McKnight, D.M., Jaros, C., Barrett, J.E., 2008.Hydrological response to extreme warm and cold summers in the McMurdo Dry Valleys, East Antarctica.Antarct. Sci. 20(5), 499-509.

Downey, R.V., Griffiths, H.J., Linse, K., Janussen, D., 2012.Diversity anddistribution patterns in high southern latitude sponges.PLoSONE.7(7), e41672.doi:10.1371/journal.pone.0041672

Duprat, P.A.M., Bigg, G.R., Wilton, D.J., 2016. Enhanced Southern Ocean marine productivity due to fertilization by giant icebergs. Nat. Geosci.doi:10.1038/ngeo263

Fillinger,L., Janussen, D., Lundälv, T., Richter, C.,2013.Rapid glass sponge expansion after climate-induced Antarctic ice shelf collapse.Curr. Biol. 23, doi:10.1016/j.cub.2013.05.051

Gili, J.M., Arntz, W.E., Palanques, A., Orejas, C,Clarke, A., Dayton, P.K., Isla, E., Teixido, N., Rossi, S., Lopez-Gonzalez, P.J., 2006. A unique assemblage of epibenthic sessile suspension feeders with archaic features in the high-Antarctic.Deep-Sea Res. Pt. II. 53, 1029-1053.

Gili, J.M., Coma, R., Orejas, C., López-González, P.J., Zavala, M., 2001.Are Antarctic suspension feeding communities different from those elsewhere in the world? Polar Biol. 24, 473-485.

Gutt, J., 2001.On the direct impact of ice on marine benthic communities.Polar Biol. 24, 553-564.

Gutt, J., 2007. Antarctic macro-zoobenthic communities: a review and an ecological classification. Antarct.Sci. 19, 165-182.

Gutt, J., Barratt, I., Domack, E., d’Udekemd'Acoz,C., Dimmler, W., Grémare, A., Heilmayer, O., 
Isla, E., Janussen, D., Jorgensen, E., Kock, K.-H., Lehnert, L.S., López-Gonzáles, P., Langner, S., Linse, K., Manjón-Cabeza, M.E., Meißner, M., Montiel, A., Raes, M., Robert, H., Rose, A., SañéSchepisi, E., Saucède, T., Scheidat, M.,Schenke, H.-W., Seiler, J., Smith, C.,2011.Biodiversity change after climate-induced ice-shelf collapse in the Antarctic. Deep-Sea Res. II. 58, 74-83.

Gutt, J., Bertler, N., Bracegirdle, T.J., Buschmann, A., Comiso, J., Hosie, G., Isla, E., Schloss, I.R., Smith, C.R., Tournadre, J., Xavier, J.C., 2015a. The Southern Ocean ecosystem under multiple climate stresses - an integrated circumpolar assessment. Global Change Biol. 21, 14341453; doi: 10.1111/geb.12794

Gutt, J., Cape, M., Dimmler, W., Fillinger, L., Isla, E., Leib, V., Lundalv, T., Pulcher, C., 2013.Shifts in Antarctic megabenthic structure after ice-shelf disintegration in the Larsen area east of the Antarctic Peninsula.Polar Biol. 36, 895-906.

Gutt, J., Cummings, V., Dayton, P.K., Isla, E., Jentsch, A., Schiaparelli, S., 2015b. Antarctic Marine Animal Forests - three-dimensional communities in Southern Ocean ecosystems,in:Rossi, S., Bramanti, L., Gori, A., Orejas, C. (Eds.), Marine Animal Forests. Springer, Major Reference Works Series. Berlin.

Gutt J., Piepenburg, D., 2003.Scale-dependent impact on diversity of Antarctic benthos caused by grounding of icebergs.Mar. Ecol.-Prog.Ser. 253, 77-83.

Hewitt, J.E., Thrush, S.F.,Dayton, P.K., Bonsdorff, E., 2007.The effect of spatial and temporal heterogeneity on the design and analysis of empirical studies of scale-dependent systems.Am. Nat. 169(3), 398-408.

Hill, M.S., 1998. Spongivory on Caribbean reefs releases corals from competition with sponges. Oecologia. 117(1-2), 143-150.

Johnson, J.S., Hillenbrand, C.-D., Smellie, J.L., Rocchi, S., 2008. The last deglaciationof Cape 
Adare, Northern Victoria Land, Antarctic.Antarct. Sci. 20(6), 581-587.

Kersken, D., Feldmeyer, B.,Janussen, D., 2016. Sponge communities of the Antarctic Peninsula Influence of environmental variables on species composition and richness. Polar Biol. 39(5), 851-862.doi:10.1007/s00300-015-1875-9

Kuffner, I.B., Paul, V.J., 2004. Effects of the benthic cyanobacteriumLyngbyamajuscula on larval recruitment of the reef corals Acroporasurculosa and Pocilloporadamicornis. Coral Reefs. 23(3), 455-458.

Leys, S.P., Degnan, B.M., 2001.Cytological basis of photoresponsive behavior in a sponge larva.Biol. Bull. 201, 323-338.

Li, C., Ren, J., Xiao, C., Hou, S., Ding, M., Qin, D., 2015. A 2680-year record of sea ice extent in the Ross Sea and the associated atmospheric circulation derived from the dt401 east Antarctic ice core. Sci. China Earth Sci. 58(11), 2090-2102.doi10.1007/s11430-015-5125-3

Littlepage, J.L., 1965. Oceanographic investigations in McMurdo Sound, Antarctica.Antar. Res. S. 5, 1-37.

Maldonado, M., Aguilar, R., Bannister, R.J., Bell, D., Conway, K.W., Dayton, P.K., Díaz, C., Gutt, J., Kenchington, E.L.R., Leys, D., Pomponi, S.A., Rapp, H.T., Rützler, K., Tendal, O.S., Vacelet, J., Young, C.M., in press. Sponge grounds as key marine habitats: a synthetic review of types, structure, functional roles, and conservation concerns, in:Rossi S., Bramanti, L. Gori A., Orejas, C. (Eds.) Marine Animal Forests. Springer, Major Reference Works Series, Berlin.

Maldonado, M., Bergquist, P.R., 2002.Phylum Porifera, in: Young, C.M. (Ed.), Atlas of marineinvertebrate larvae. Academic Press, San Diego, California, pp. 21-50.

McClintock, J.B., Amsler, C.D., Baker, B.J., van Soest, R.W.M., 2005. Ecology of Antarctic marine sponges: An overview. Integr. Comp. Biol. 45(2), 359-368. 
Mikucki, A., Auken, E., Tulaczyk, S., Virginia, R.A.,Schamper, C., Sørensen, K.I., Doran, P.T., Dugan, N., Foley, N., 2015.Deep groundwater and potential subsurface habitats beneath an Antarctic dry valley.Nat. Commun. 6, Article number 6831.doi:10.1038/ncomms 7831

Mileikovsky, S.A., 1974. On predation of pelagic larvae and early juveniles of marine bottom invertebrates by adult benthic invertebrates and their passing alive through their predators.Mar. Biol. 26, 303-311.

Montes-Hugo, M., Doney, S.C., Ducklow, H.W., Fraser, W., Martinson, D., Stammerjohn, S.E., Schofield, O., 2009. Recent changes in phytoplankton communities associated with rapid regional climate change along the Western Antarctic Peninsula. Science. 323, 1470-1473.

Oliver, J.S., Slattery, P.N., 1985.Effects of crustacean predators on speciescomposition and population structure of soft-bodied infauna from McMurdoSound, Antarctica. Ophelia. 24, 155175.

Orejas, C., Gili, J.M., Arntz, W.E., Ros, J.D., López P.J., Teixidó, N., Filipe, P., 2000.Benthic suspensionfeeders, key players in Antarctic marine ecosystems? Contrib. Sci. 1(3),299-311.

Peck, L. S., Brockington, S., Vanhove, S., Beghyn, S., 1999. Community recovery following catastrophic iceberg impacts in a soft-sediment shallow-water site at Signy Island, Antarctica.Mar. Ecol.-Prog.Ser. 186, 1-8.

Reiswig, H.M., 1973. Water transport, respiration and energetics of 3 tropical marine

sponges. J. Exp. Mar. Biol. Ecol. 14, 231-249.

Reiswig, H.G., 1990. In situ feeding in two shallow water hexactinellid sponges, in:Rutzler, K. (Ed.), New Perspectives in Sponge Biology. Smithsonian Institution Press, Washington D.C., pp. 7-20. 
Sahade, R., Lagger, C., Torre, L., Momo, P., Monien, P., Schloss, I., Barnes, D.K.A., Servetto, N., Tarantelli, S., Zamboni, N., Abele, D. 2015. Climate change and glacier retreat drive shifts in an Antarctic benthic ecosystem. Science Advances. 1(10), e1500050.doi:

10.1126/sciadv. 1500050

Suhr, S.B., Alexander, S.P., Gooday, A.J., Pond, D.E., Bowser, S.S., 2008. Trophic

modes of large Antarctic Foraminifera: roles of carnivory, omnivory, and detritivory. Mar. Ecol.-Prog. Ser. 371, 155-164.

Teixidó, N, Gili, J.M., Uriz, M.-J., Gutt, J, Arntz, W., 2006. Observations of asexual reproductive strategies in Antarctic hexactinellid sponges from ROV video records. Deep-Sea Res. 2, 972-984.

Thatje, S., Hillenbrand, C.-D., Mackensen, A.,Larter, R., 2008. Life hung by a thread: endurance of Antarctic fauna in glacial periods. Ecology. 89(3), 682-692.

Thorson, G., 1966. Some factors influencing the recruitment and establishment of benthic marine communities. Neth. J. Sea Res. 3(2), 267- 293.

Thrush, S.P., Cummings, V.J., 2011.Massive icebergs, alteration in primary foodresources and change in benthic communities at Cape Evans, Antarctica. MarEcol. 32, 289-299.

Thrush, S., Dayton, P., Cattaneo-Vietti, R., Chiantore, M., Cummings, V., Andrew, N., Hawes, I., Kim, S., Kivitek, S., Schwarz, S., 2006. Broad-scale factors influencing the biodiversity of coastal benthic communities of the Ross Sea. Deep-Sea Res. Pt II. 53, 959-971.

Thrush, S., Dayton, P., 2010. What can ecology contribute to ecosystem-based management?Annu. Rev. Mar. Sci. 2, 419-441. 
Thrush, S.F., Hewitt, J.E., Dayton, P.K., Coco, G., Lohrer, A.M., Norkko, A.,Norkko, J., Chiantore, M., 2009.Forecasting the limits of resilience: integrating empirical research with theory. P. Roy. Soc. B. 276, 3209-3217.

Thurber, A.R., 2007. Diets of Antarctic sponges: links between the pelagic microbial loop and benthic metazoan food web. Mar. Ecol.-Prog. Ser. 351, 77-89.

Torre, L., Servetto, N., Eory, M.L., Momo, F., Tatian, M., Abele, D., Sahade, D., 2012. Respiratory responses of three Antarctic ascidians and a sea pen to increased sediment concentrations. Polar Biol. 35(11), 1743-1748.

Turner J, Barrand NE, Bracegirdle TJ, Convey P, Hodgson D, Jarvis M, Jenkins A, Marshall G, Meredith MP, Roscoe H, Shanklin J, French J, Goosse H, Gutt J, Jacobs S, Kennicutt II MC, Masson-Delmotte V, Mayewski P, Navarro F, Robinson S, Scambos T, Sparrow M, Summerhayes C, Speer K, Klepikov A 2014. Antarctic climate change and the environment: an update. Polar Record 50: 237-259

Yahel, G., Whitney, F., Reiswig, H.M., Eerkes-Medrano, D.I., Leys, S.P., 2006. Sizeindependent selective filtration of ultraplankton by hexactinellid glass sponges.Aquat. Microb. Ecol. 45, 185194. 


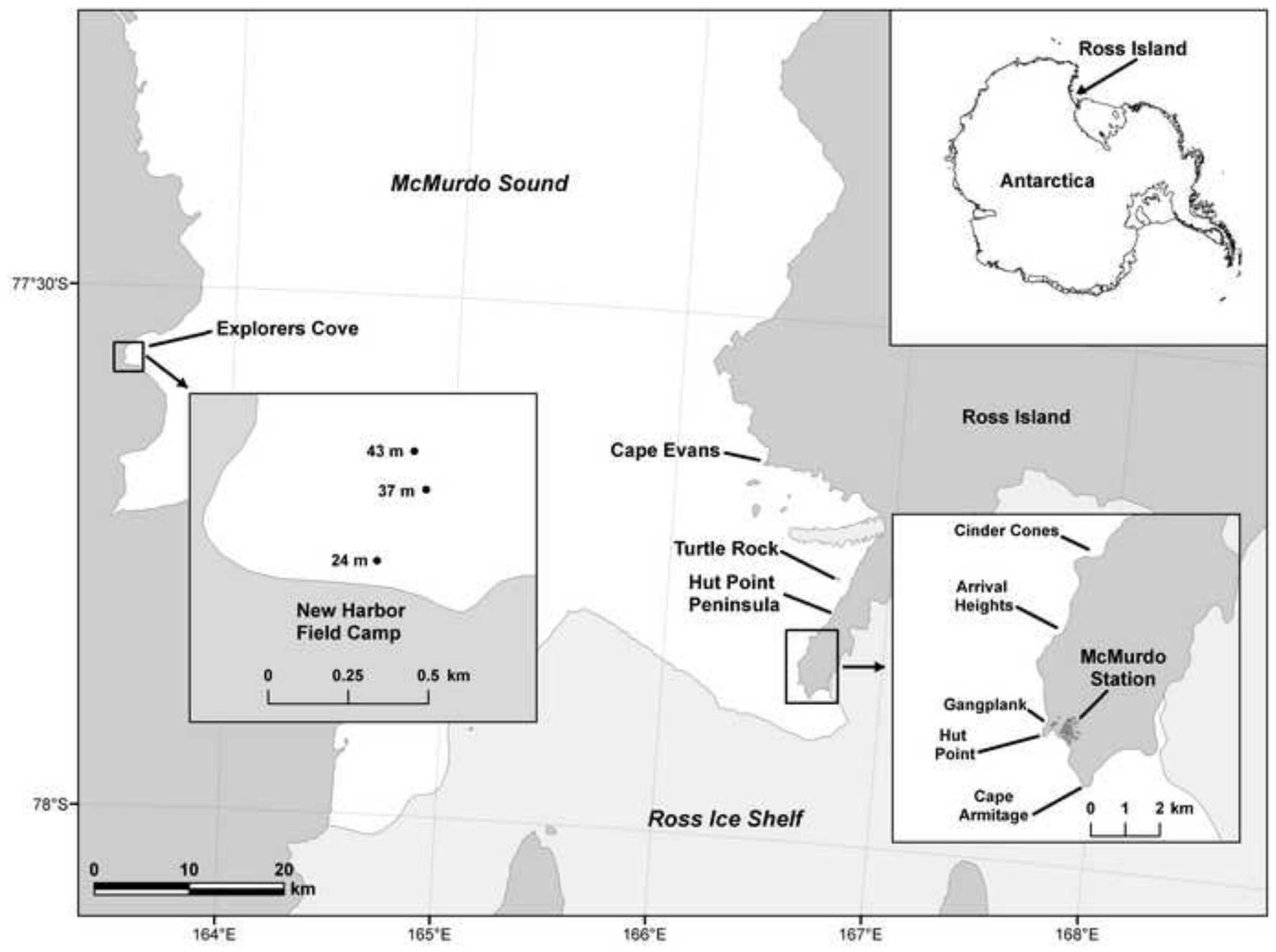




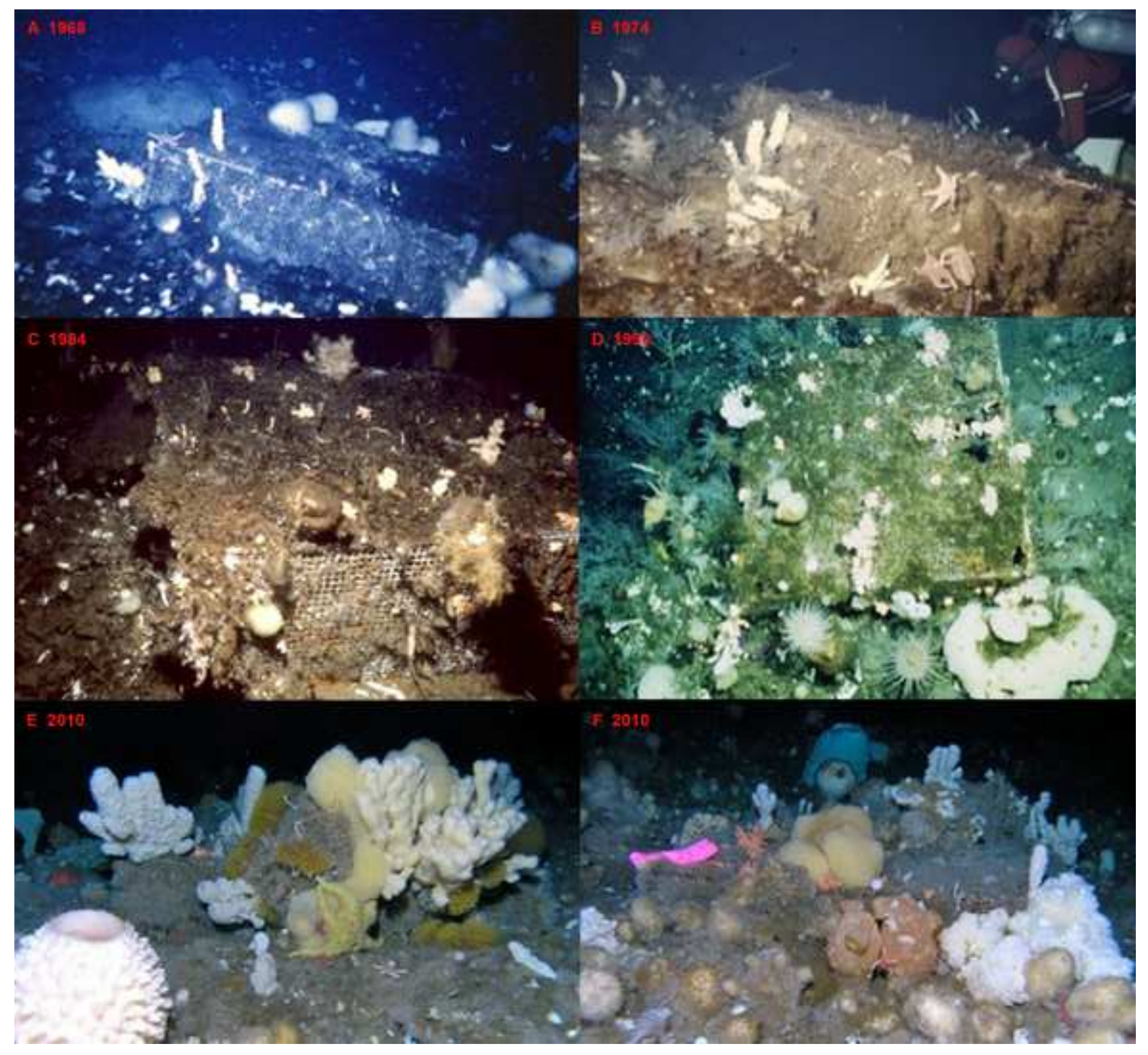

$$
\begin{aligned}
& \text { Avan a }
\end{aligned}
$$

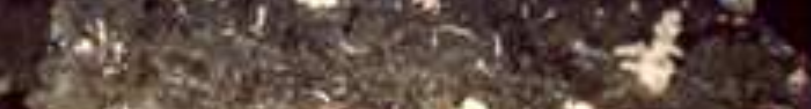

5.9.8.

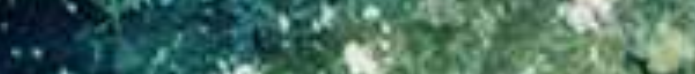

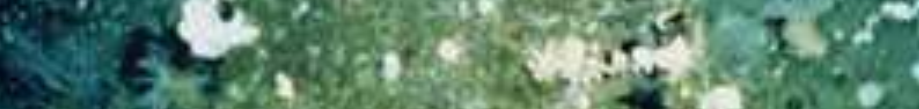

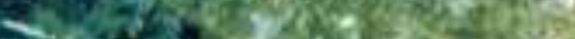

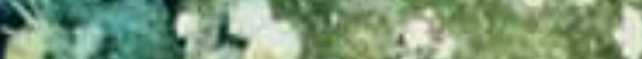
$2)^{2}+\frac{1}{2}$

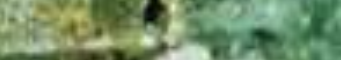
4 , $10 \times$ IF 2010 . 


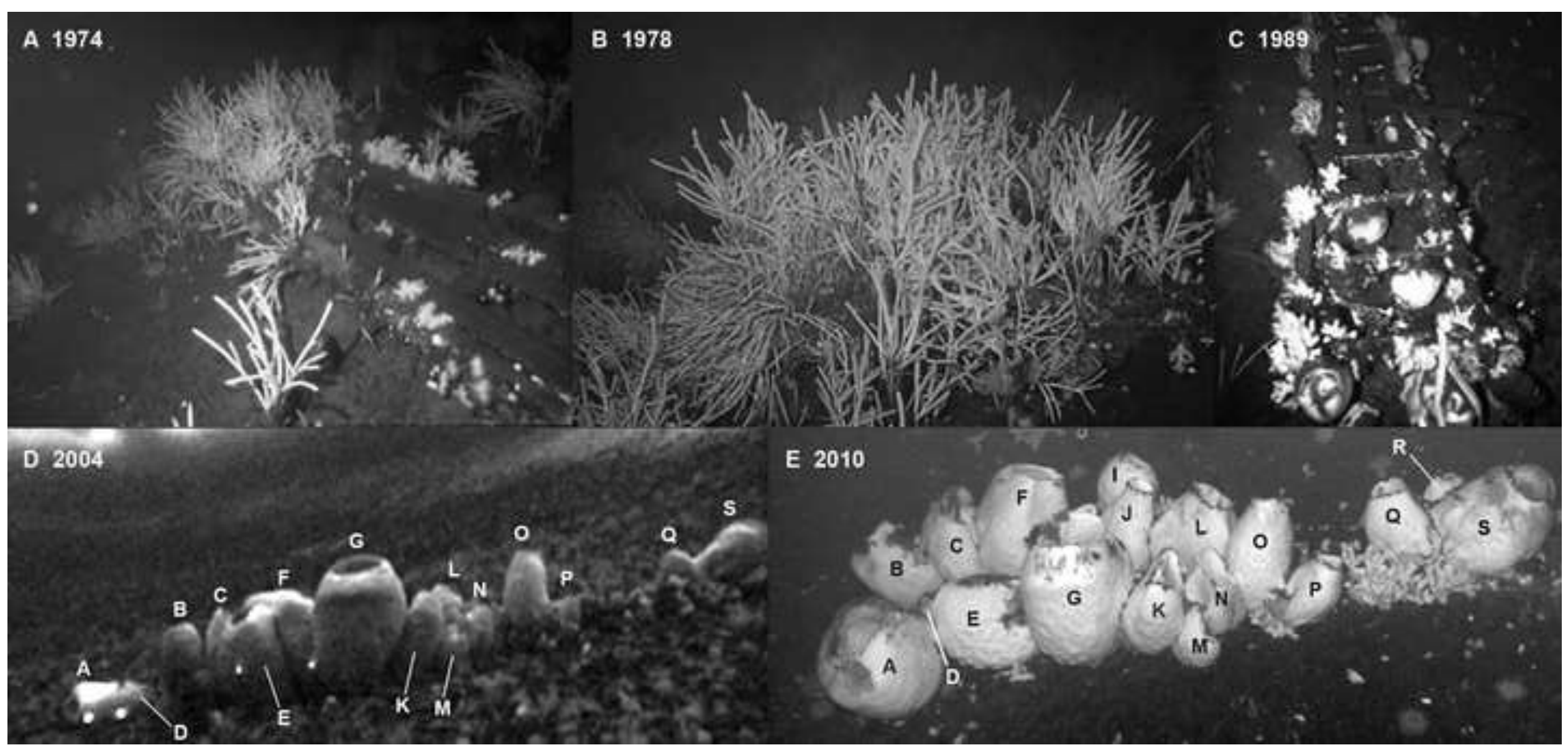

D 2004
10
(5) 589

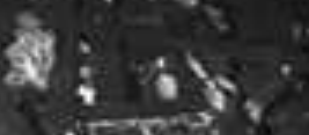
(4) and res $10 \%$ sed sto $x^{2}+2 y+3$

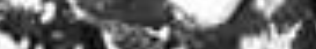
1. $20,1,3$ \& $28)=901$ R. 


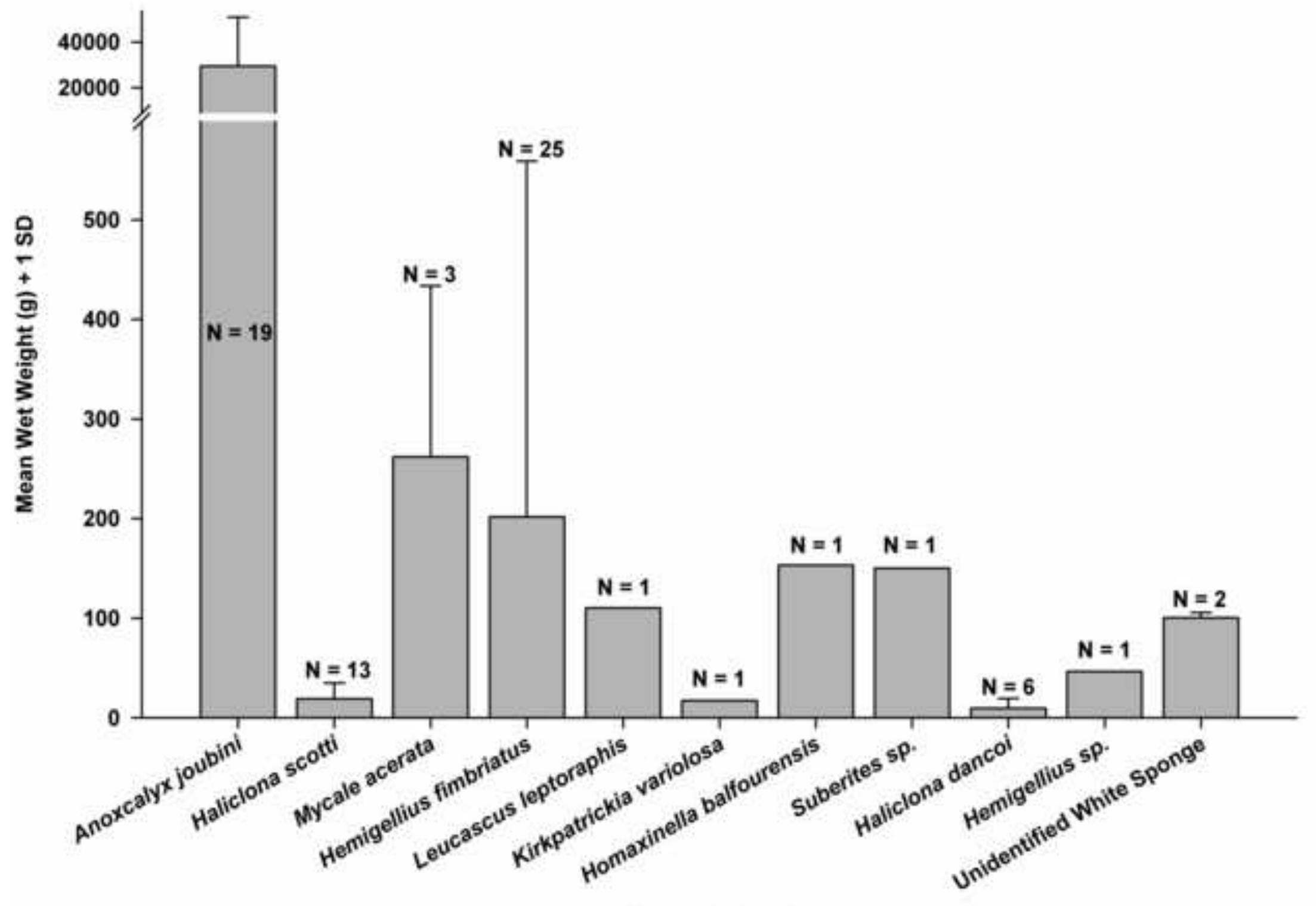

Sponge Species 


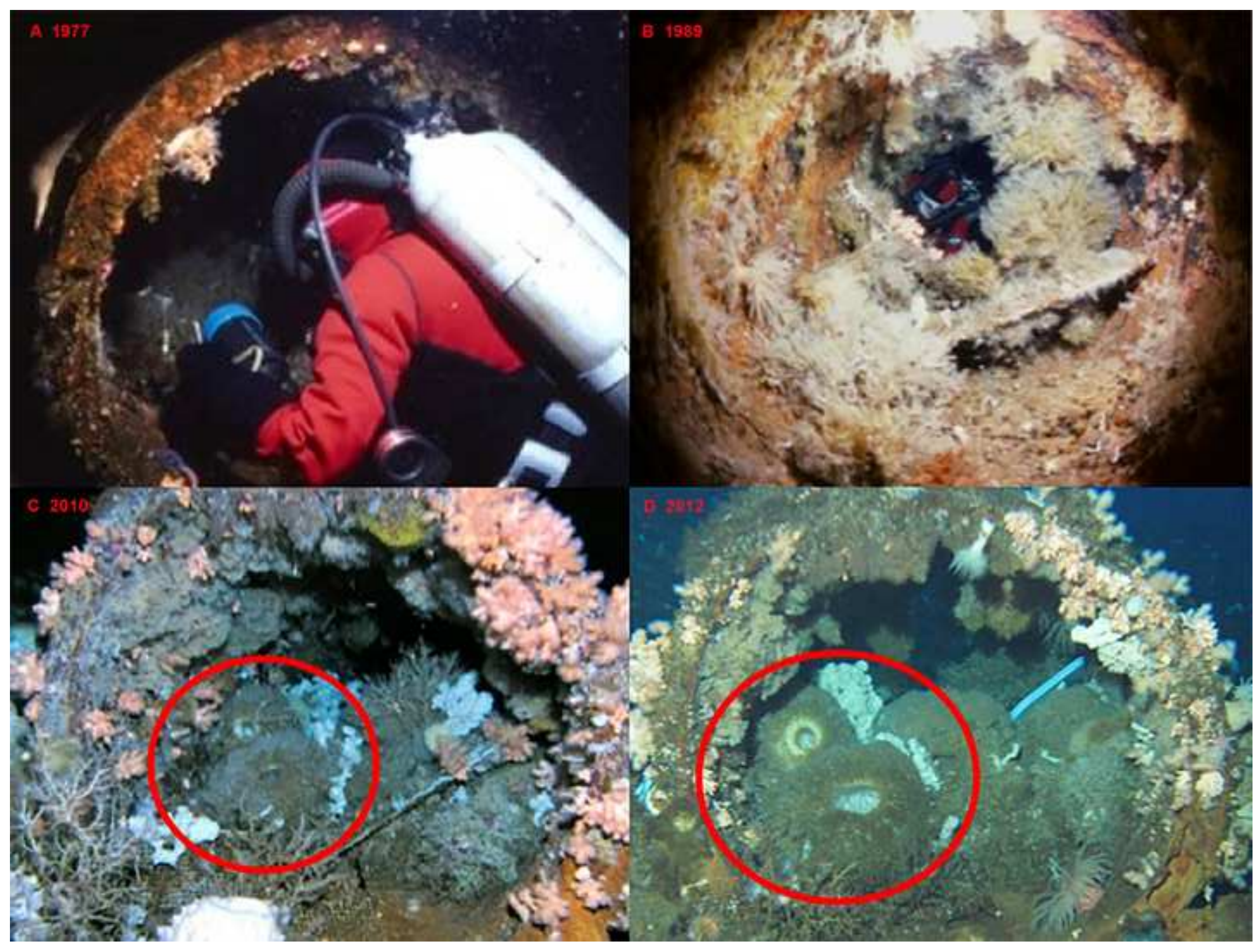




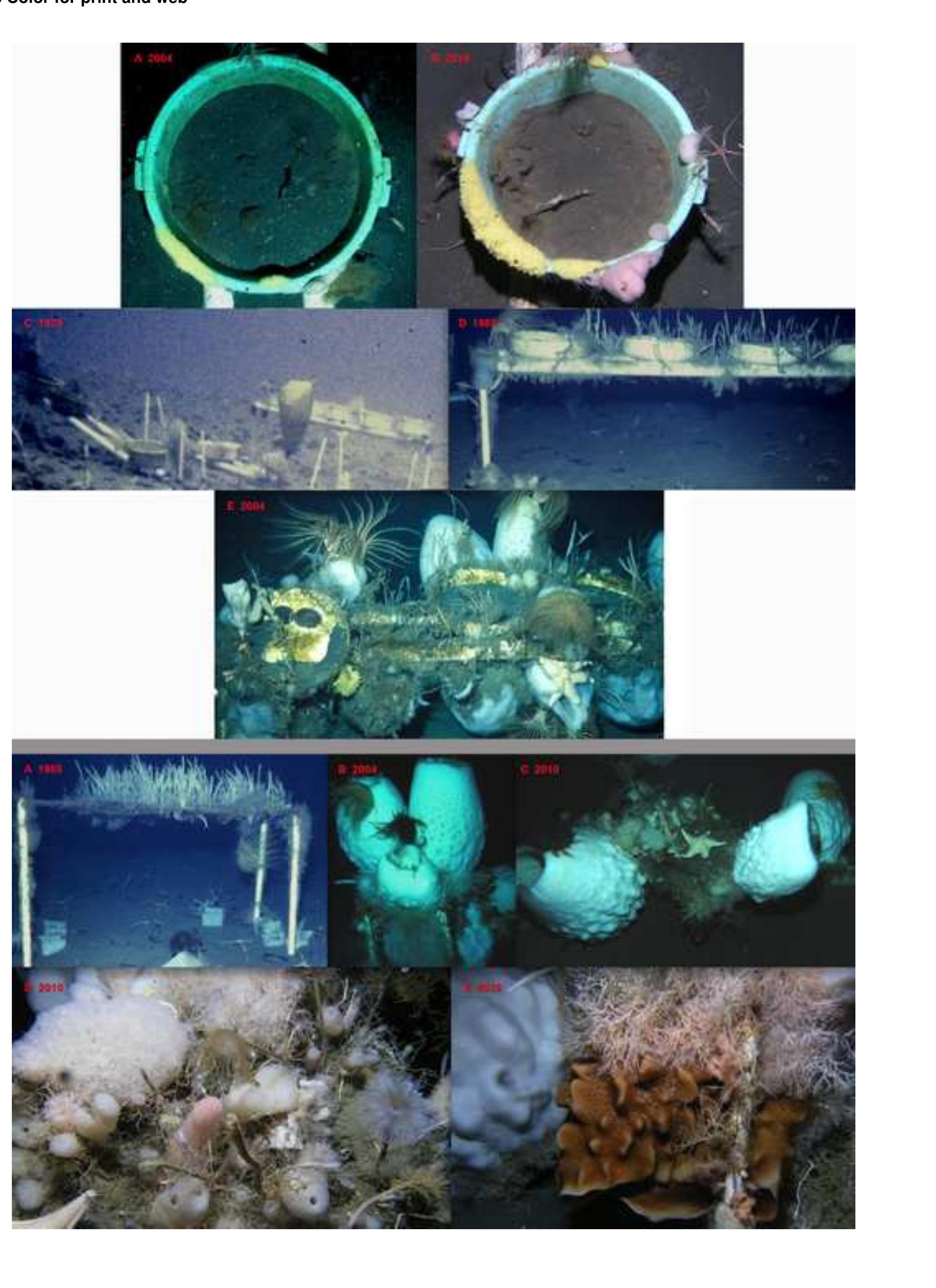

Figure 6 Color for print and web

\section{print and web}

\section{wa

(eb
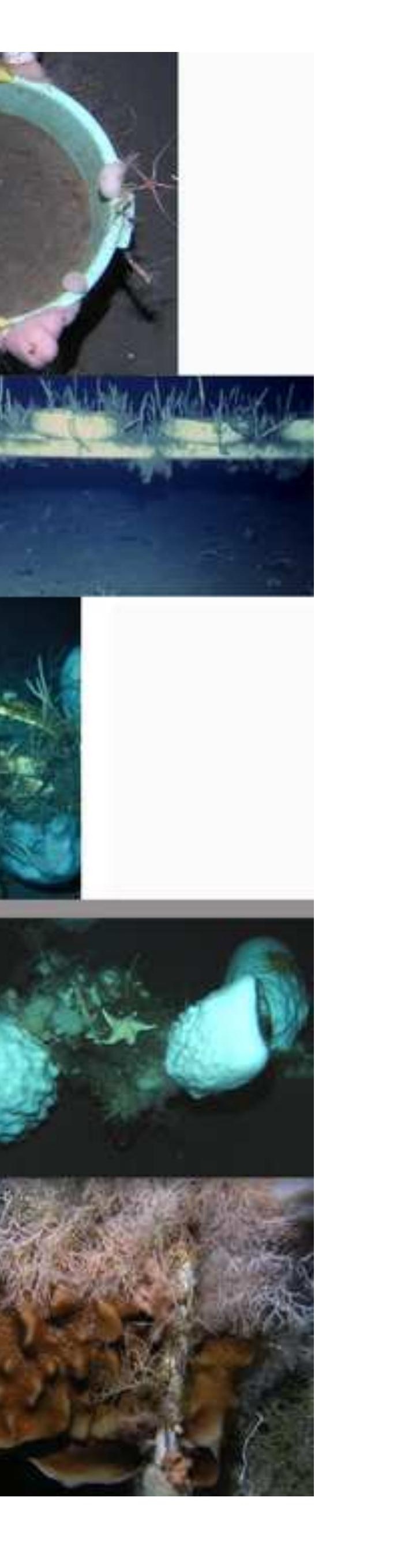


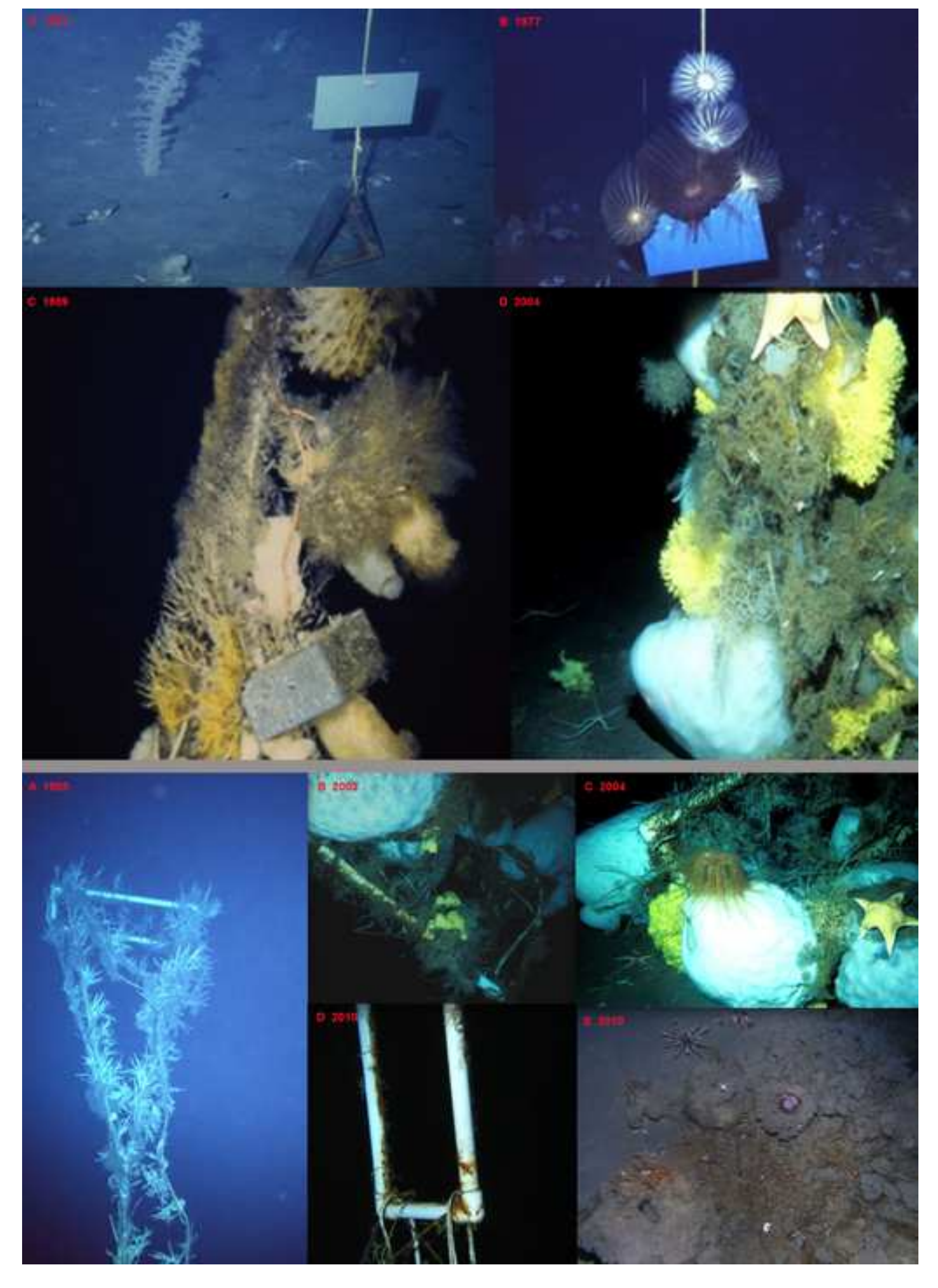

Figure 7 Color for print and web

\section{Figure 7 Color for print and web}

\section{b} .

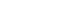

.

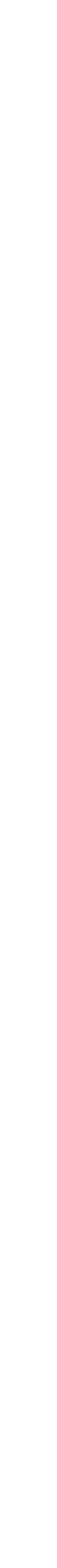

